\title{
Late Glacial and Holocene sedimentary infill of Lake Mondsee (Eastern Alps, Austria) and historical rockfall activity revealed by reflection seismics and sediment core analysis
}

\author{
Christoph DAXER ${ }^{\left.1)^{*}\right)}$, Jasper MOERNAUT ${ }^{1)}$, Timothy TAYLOR ${ }^{2)}$, Jean Nicolas HAAS ${ }^{3)}$ \& Michael STRASSER ${ }^{1)}$ \\ 1) Institute of Geology, University of Innsbruck, Innrain 52f, 6020 Innsbruck, Austria; \\ 2) Department of Prehistoric and Historical Archaeology, University of Vienna, Franz-Klein-Gasse 1, 1190 Vienna, Austria; \\ 3) Institute of Botany, University of Innsbruck, Sternwartestrasse 15, 6020 Innsbruck, Austria; \\ *) Corresponding author: Christoph.Daxer@uibk.ac.at
}

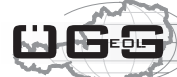

KEYWORDS Seismic stratigraphy; rockfalls; lake sediments; Mondsee; Eastern Alps; Austria

\begin{abstract}
Glacigenic perialpine lakes can constitute continuous post-last glacial maximum (LGM) geological archives which allow reconstruction of both lake-specific sedimentological processes and the paleoenvironmental setting of lakes. Lake Mondsee is one among several perialpine lakes in the Salzkammergut, Upper Austria, and has been previously studied in terms of paleoclimate, paleolimnology and (paleo)ecology. However, the full extent and environment of Late Glacial to Holocene sediment deposition had remained unknown, and it was not clear whether previously studied core sections were fully representative of 3D sediment accumulation patterns.

In this study, the sedimentary infill of Lake Mondsee was examined via high-resolution seismic reflection survey over a $57-\mathrm{km}$ extent ( $3.5 \mathrm{kHz}$ pinger source) and a sediment core extracted from the deepest part of the lake, with a continuous length of $13.76 \mathrm{~m}$. In the northern basin, seismic penetration is strongly limited in most areas because of abundant shallow gas (causing acoustic blanking). In the deeper areas, the acoustic signal reaches depths of up to 80 ms TWT (two-way travel time), representing a postglacial sedimentary sequence of at least $60-\mathrm{m}$ thickness. Holocene deposits constitute only the uppermost $11.5 \mathrm{~m}$ of the sedimentary succession. Postglacial seismic stratigraphy of Lake Mondsee closely resembles those of well-studied French and Swiss perialpine lakes, with our data showing that most of Lake Mondsee's sedimentary basin infill was deposited within a short time period (between 19,000 BP and 14,500 BP) after the Traun Glacier retreated from the Mondsee area, indicating an average sedimentation rate of about $1.4 \mathrm{~cm} / \mathrm{yr}$.

Compared to other perialpine lakes, the seismic data from Lake Mondsee reveal little indication of mass movement activities during the Holocene. One exception, however, is rockfalls that originate from a steep cliff, the Kienbergwand, situated on the southern shore of Lake Mondsee, where, in the adjacent part of the lake, seismic profiles show mass transport deposits (MTDs), which extend approximately $450 \mathrm{~m}$ from the shore and are mappable over an area of about 45,300 $\mathrm{m}^{2}$. Sediment cores targeting the MTDs show two separate rockfall events. The older event consists of clast-supported angular dolomitic gravels and sands, showing high amounts of fine fraction. The younger event exhibits dolomitic clasts of up to $1.5 \mathrm{~cm}$ in diameter, which is mixed within a lacustrine muddy matrix. Radiocarbon dating and correlations with varve-dated sediment cores hint at respective ages of $A D 1484 \pm 7$ for Event 1 and AD $1639 \pm 5$ for Event 2. As our data show no evidence of larger-scale mass movements affecting Lake Mondsee and its surroundings, we infer that the current-day morphology of the Kienbergwand is the result of infrequent medium-scale rockfalls.
\end{abstract}

\section{Zusammenfassung}

Perialpine Seen stellen kontinuierliche geologische Archive dar und ermöglichen die Rekonstruktion von see-internen Sedimentationsprozessen und der Umgebung des Sees vom letzteiszeitlichen Maximum bis heute.

Der Mondsee ist einer von vielen perialpinen Seen des Salzkammergutes in Oberösterreich und wurde bisher anhand von Seebohrkernen im Hinblick auf Paläoklima, Paläolimnologie und (Paläo-)Ökologie untersucht. Die Sedimentfüllung des Sees wurde jedoch bisher nie mithilfe einer Kombination aus Sedimentkernen und reflexionsseismischen Profilen erforscht. Somit sind die dreidimensionalen Ablagerungsmuster, das vollständige Ausmaß und die Ablagerungsbedingungen des spätglazialen bis holozänen Sediments noch unbekannt.

Im Zuge dieser Studie wurde die Sedimentfüllung des Mondsees mithilfe von etwa $57 \mathrm{~km}$ an reflexionsseismischen Profilen (3.5 kHz System) und eines 13,76 m langen Sedimentkernes aus dem tiefsten Bereich des Sees untersucht. Im Nordbecken ist die Reichweite der akustischen Wellen durch stark gashaltiges Sediment bis auf wenige Bereiche stark limitiert. Im tieferen Bereich reicht das verwertbare akustische Signal bis in eine Tiefe von etwa 80 ms TWT (two-way travel time). 
Die Sedimentmächtigkeiten betragen über 60 m, wobei die holozänen Ablagerungen nur etwa die obersten 11,5 m ausmachen. Die postglaziale seismische Stratigraphie hat große Ähnlichkeiten zu jener der gut untersuchten Voralpenseen Frankreichs und der Schweiz. Unsere Daten zeigen, dass der Großteil des Sediments innerhalb einer kurzen Zeitspanne (19000 bis 14500 BP) abgelagert wurde, nachdem sich der Traungletscher aus dem Mondseegebiet zurückgezogen hatte. Die Sedimentationsraten für diesen Zeitraum liegen im Bereich von $1.4 \mathrm{~cm} / \mathrm{Jahr}$.

Verglichen mit anderen perialpinen Seen geben die seismischen Daten des Mondsees wenig Hinweis auf Massenbewegungen während des Holozäns. Eine Ausnahme bilden hier jedoch Felssturzereignisse an der sogenannten Kienbergwand, einer steilen Felswand am Südufer des Mondsees. Hier zeigen sich Ablagerungen von Massenbewegungen in den seismischen Profilen, welche sich etwa $450 \mathrm{~m}$ in den See erstrecken. Diese Ablagerungen sind über eine Fläche von $45300 \mathrm{~m}^{2}$ kartierbar. Sedimentkerne aus den Ablagerungsgebieten zeigen zwei Felssturzereignisse an. Das ältere Ereignis besteht aus korngestützten angularen dolomitischen Kiesen und Sanden mit hohem Feinanteil, das jüngere ist durch in einer feinen lakustrinen Matrix schwimmende Dolomitklasten charakterisiert. Radiokarbondatierungen und Korrelationen zu varven-datierten Sedimentkernen erlauben eine zeitliche Einordnung der Felssturzereignisse um die Jahre $1484 \pm 7$ und $1639 \pm 5$ nach Christus. Die heutige Morphologie der Kienbergwand ist das Resultat mehrerer kleinerer und mittlerer Felsstürze, die nur in geringer Häufigkeit auftreten. Unsere Daten zeigen keine Anzeichen für große Massenbewegungen in der Umgebung des Mondsees oder im See selbst.

\section{Introduction}

Perialpine lakes, created by glacial erosion during past glacial maxima, represent excellent geological archives that record the deglaciation and postglacial evolution of lake basins and their surroundings (Cohen, 2003; Hinderer, 2001; Preusser et al., 2010; among others). Besides information about environmental evolution during the late Quaternary (e.g. Lauterbach et al., 2011), the imprints of high-energy natural events such as floods (Schillereff et al., 2014; Simonneau et al., 2013) along with debris flows (Sletten et al., 2003; Lastras et al., 2013), rockfalls (Bussmann and Anselmetti, 2010), shore collapses (Longva et al., 2003), and lake internal sediment remobilisation caused by strong seismic shaking (Kremer et al., 2017; Moernaut et al., 2017) are all preserved in lake sediments. These natural phenomena are associated with potential danger and pose a particular risk to nearshore settlements: sediment or rockfall masses entering lakes at high velocity have been demonstrated to cause catastrophic waves in the past (Hilbe \& Anselmetti, 2015; Huber, 1982; Kremer et al., 2012; Schnellmann et al., 2002). It is therefore of potential benefit to assess recurrence rates of such events and understand their spatio-temporal distribution. To do this, an ability to distinguish the lacustrine fingerprints of different sedimentological events is crucial.

In the Lake Mondsee area (Salzkammergut, Austria), the type and distribution of terrestrial mass movements are closely linked to regional geology (Fig. 1A): in the Rhenodanubian Flysch zone, sliding and creeping predominate, whereas the most competent rocks of the Northern Calcareous Alps (NCA) tend to be associated with rockfalls and rock avalanches (Geologische Bundesanstalt, 2017). Over the course of the past $\sim 70$ years, a few small-scale rockfalls were reported in the Mondsee area, some of which occurred near the "Kienbergwand", the near vertical cliff face that forms the extreme southern shore (Fig. 1B; Geologische Bundesanstalt, 2017; OTS, 1999). The dramatic natural setting here has prompted hypotheses concerning a major event, a rockfall originating in the southeast of the lake (red star on Fig. 1A), which could have caused a catastrophic "Mondsee Tsunami", which has then, in turn, been cited as responsible for an abandonment of Neolithic lake dwellings 5000 years ago (Schulz, 2008). This hypothesis is highly debatable from an archaeological viewpoint (Breitwieser, 2010; the chronology and nature of prehistoric lacustrine settlement on Lake Mondsee have to date remained underdetermined). In addition, although Janik (1969) found evidence of rockfall material near the outflow of the Seeache river in the form of large boulders, the sedimentary archive of Lake Mondsee has never before been investigated in detail regarding possible rockfall/tsunami events.

Lake Mondsee - as one of many perialpine lakes has previously been studied with a focus on sedimentological (Irlweck \& Danielopol, 1985; Kämpf et al., 2014, 2015; Swierczynski et al., 2009), paleoclimatic (Andersen et al., 2017; Lauterbach et al., 2011), paleolimnological (Klee \& Schmidt, 1987; Schmidt, 1991; Swierczynski, 2012; Swierczynski et al., 2013) and paleoecological/paleoethnobotanical (Kowarik et al. 2017; Namiotko et al., 2015; Schultze \& Niederreiter, 1990) perspectives using sediment cores retrieved mostly from the deepest part of the lake. However, the sedimentary infill of Lake Mondsee has not previously been studied by means of seismic stratigraphy including spatial investigation of event-related mass movement depositions. Thus, event layers observed in the sediment cores remained to be investigated in terms of their relevance for basin-wide sedimentation patterns vs. mass movement processes.

In this study, we (1) resolve the 3D lake infill with reflection seismic methods to evaluate Late Glacial to Holocene sedimentary dynamics in Lake Mondsee; (2) trace the spatial distribution of event layers, allowing us to distinguish different origins of the layers described by Swierczynski (2012) and (3) identify, describe and date the mass movement and rockfall events visible in the seismic and sedimentary record of Lake Mondsee. 


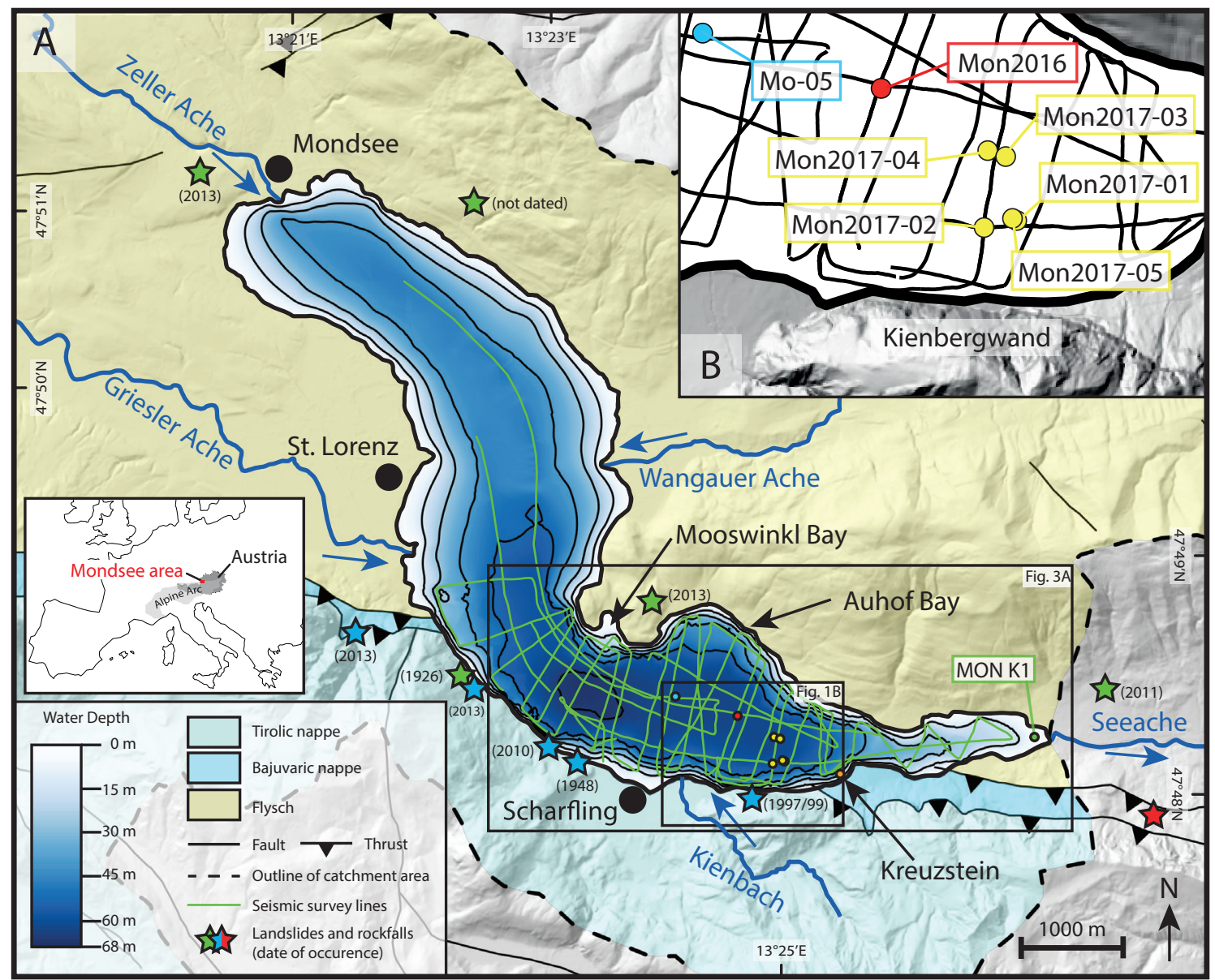

Figure 1: Location of Lake Mondsee (Salzkammergut, Austria) and data coverage. A) Simplified tectonic (modified after van Husen, 1989) and bathymetric map of Lake Mondsee calculated based on the seismic data acquired in the southern sub-basin (green lines) and the contour lines provided by the Austrian topographic map (ÖK 50) where seismic data are scarce. The dashed line indicates the outline of the catchment area (see e.g. Lauterbach et al. (2011) for full map). Recent mass movements recorded by the Austrian Geological Survey (Geologische Bundesanstalt, 2017) are depicted as blue (rockfalls) and green (landslides) stars. The red star in the southeast indicates the presumed rockfall related to the highly debated "Mondsee Tsunami" (Breitwieser, 2010; Schulz, 2008). The core MON K1 analysed by Behbehani (1987) was taken at the location depicted by a green circle. B) Close-up map of coring locations (see Supplementary Table 1 for coordinates). Short cores are depicted in yellow, the Mon2016 core in red and core Mo-05 (e.g. Lauterbach et al., 2011) in blue.

\section{Study Area}

\subsection{Hydrological and geological setting of the Lake Mondsee area}

Lake Mondsee is an oligo-mesotrophic hardwater lake located at the northern margin of the Austrian Alps $\left(47^{\circ} 49^{\prime} \mathrm{N}, 13^{\circ} 22^{\prime} \mathrm{E}\right.$; Fig. $\left.1 \mathrm{~A}\right)$ in the federal state of Upper Austria, $481 \mathrm{~m}$ above sea level. The lake basin (area: $13.8 \mathrm{~km}^{2}$; volume: $0.51 \mathrm{~km}^{3}$ ) can be subdivided into two parts: an NW-SE-oriented shallow basin (of max. 50-m water depth) in the north-to-north-western part and a deeper WNW-ESE-oriented basin (max. depth $68 \mathrm{~m}$; Jagsch and Megay, 1982) striking parallel to the main tectonic boundary between the NCA and the Flysch zone. The basins were formed and repeatedly modified by the Pleistocene glacial activity of the Traun glacier (Egger and van Husen, 2009; van Husen, 2004; van Husen and Egger, 2014). Following the final retreat of the Traun glacier, the catchment area (ca. $241 \mathrm{~km}^{2}$ ) may be subdivided into (1) the smaller southern part (25\%), consisting of the Mesozoic dolomites and limestones of the NCA, and (2) the northern part (75\%), comprising the siliciclastic sediments of the Rhenodanubian Flysch zone (van Husen and Egger, 2014).

Lake Mondsee is fed by three main tributaries (Fig. 1A) that account for more than $70 \%$ of the water inflow (Gumpinger, 2011) draining the predominant Rhenodanubian Flysch zone catchment in the north. The Zeller Ache ("Ache" = rivulet), with a catchment area of $38.4 \mathrm{~km}^{2}$, drains from the smaller Lake Irrsee in the northwest, which acts as a sediment trap to reduce sediment flux into Lake Mondsee from this area, while the Wangauer Ache (catchment area $35.3 \mathrm{~km}^{2}$ ) from the northeast and the Griesler Ache $\left(117.6 \mathrm{~km}^{2}\right)$ from the west jointly account for the main siliciclastic sediment flux into Lake Mondsee (Kämpf et al., 2015) and form the convex lakeward shoreline morphologies typical for lacustrine delta systems (Fig.1A). Another tributary, the Kienbach brook, has its catchment area in the NCA and enters Lake Mondsee from the south in the vicinity of Scharfling (Fig. 1A). Lake Mondsee drains into Lake Attersee via the river Seeache, which debouches at the south-easternmost end of Lake Mondsee. 
In the past century, studies on the sediments of Lake Mondsee focused mainly on historically recent changes in lake ecology related to eutrophication (Irlweck \& Danielopol, 1985; Klee \& Schmidt, 1987; Schmidt, 1991) and on general lake evolution (Behbehani et al., 1985; Löffler, 1983). Behbehani (1987) provided a low-resolution study on littoral cores up to $8 \mathrm{~m}$ in length (MON K1) taken in the easternmost part of Lake Mondsee (Fig. 1A), concentrating on Late to Post-Glacial sedimentary and climatic evolution. A basinal core, taken at a 67-m water depth and nearly $14 \mathrm{~m}$ long, was investigated by Schultze \& Niederreiter (1990), who focused on Late Glacial to Holocene vegetation change. Both of these studies, however, relied on palynological data to date the stratigraphic succession. A detailed age model of the Lake Mondsee sedimentary infill was established by Lauterbach et al. (2011), who dated a composite 15-ka profile taken from the deepest part of the lake (core Mo-05; see Fig. 1B and supplementary Table 1 for location) based on varve counting, radiocarbon dating and wiggle matching of $\delta^{18} \mathrm{O}$ values with the Greenland NGRIP record (e.g. Rasmussen et al., 2006). Analyses of flood layer formation and flood chronology (Kämpf et al., 2014, 2015; Swierczynski, 2012; Swierczynski et al., 2012, 2013) and paleoclimatic reconstructions (Andersen et al., 2017; Lauterbach et al., 2011) were performed on the same core.

\subsection{The geological setting of the Kienbergwand}

The southern shoreline of Lake Mondsee, east of Scharfling, is characterized by a prominent cliff, approximately 400-m high (Fig. 1B), the "Kienbergwand" ("wand" = cliff). This feature is part of the Tirolic nappe (Staufen-Höllengebirgsdecke, Schafbergtirolikum) and is mainly composed of Dolostones of the Triassic Hauptdolomit Formation (van Husen, 1989). Talus deposits, rockfall debris and overlain moraines constitute the foot of the Kienbergwand as it forms the southern shoreline of Lake Mondsee (Hittenberger et al., 2006), and these cover the EW trending thrust of the Tirolic nappe onto the Bajuvaric nappe, which mainly consist of conglomerates of the Gosau Group, marls (Tannheimer Schichten) and marly carbonates (Schrambachschichten) in this area (Hittenberger et al., 2006).

The Kienbergwand is affected by several joint sets and is tectonically weakened, leading to many local fissures and water discharges (Hittenberger et al., 2006). Thus, the steep rock face as it dips almost vertically into Lake Mondsee, being subject to physical weathering, is predisposed to rockfalls. Before the construction of a road tunnel through the Kienbergwand, the road at the base of the Kienbergwand was often affected by rockfalls (e.g. in 1999, when a car was hit by a 10-kg rock; OTS, 1999.), and the so-called Kreuzstein, a prominent boulder lying in Lake Mondsee, testifies to even larger rockfall activity at Kienbergwand in the past (van Husen and Egger, 2014). Further information on the physical geography here includes the information, recorded by
Schadler (1958), that waterlogged tree trunks can be found standing upright in the sediment offshore from the Kienbergwand, while divers have observed a massive overhanging block near the Kienbergwand in a 17-m water depth, reporting that the steep cliff continues to a water depth of about 20-40 m (Tourismusverband MondSeeLand, 2017). Such evidence suggests repeated instability of the Kienbergwand rock face. However, it was a matter of speculation when and how often past rockfall events had occurred in the past, and what magnitude these events might have had.

\section{Methodology}

\subsection{Seismic reflection survey and data processing}

High-resolution single-channel seismic profiles were acquired in October 2015 and again in April 2016. Both surveys were carried out using a $3.5-\mathrm{kHz}$ pinger source and a shot interval of 0.5 seconds: in 2015, a GeoAcoustics 3.5-kHz 4-element pinger (ETH Zürich) was used; in 2016, a Geopulse pinger (University of Innsbruck) served as the acoustic source and receiver. Both systems provide a theoretical vertical resolution of $10 \mathrm{~cm}$. The seismic source/receiver was mounted on an inflatable cataraft, which itself was attached to the Research Department for Limnology, Mondsee (University of Innsbruck) research vessel "Wilhelm Kuehnelt". Survey speed was about 6-7 km/h. The incoming analogue signal was converted to a digital SEG-Y format (Coda Octopus Survey Engine). Navigation was carried out using GPS and Fugawi Navigation Software, enabling an accuracy of $\pm 5 \mathrm{~m}$. Overall, $56.8 \mathrm{~km}$ of seismic profiles was acquired, focusing strongly on the southern lake basin because of low penetration depths in the NW part of the lake. Data were processed using a bandpass filter (lower cut $2 \mathrm{kHz}$, upper cut $6 \mathrm{kHz}$ ) in the IHS Kingdom (v. 2015) Seismic and Geological Interpretation Software, which was also used for volumetric analyses. The bathymetric map (Fig. 1A) was created in Surfer (Golden Software) by interpolation (Kriging method) of the picked lake floor horizon from the seismic data (and the contour lines provided by the Austrian topographic map (ÖK 50) where seismic data is scarce). For time-to-depth conversions, a constant velocity of $1500 \mathrm{~m} / \mathrm{s}$ for both water and sediment was assumed.

\subsection{Coring campaigns}

Sediment coring was carried out in June 2016, using a UWITEC Piston Corer with a drill core diameter of $60 \mathrm{~mm}$. At the location (X: 380926, Y: 5295879; 4748'19" $\mathrm{N}, 13^{\circ} 24^{\prime} 35^{\prime \prime} \mathrm{E}$ ), two parallel sister cores (Mon2016_1 and Mon2016_2) were taken with overlapping 3-m-long core barrels, which allowed core-to-core correlation between overlapping sections by distinct macroscopic lithological marker layers to establish a continuous composite core of $13.76 \mathrm{~m}$. In a second coring campaign in April 2017, five short cores labelled Mon2017-01 to Mon2017-05 were retrieved offshore, the 
Kienbergwand, using a gravity short corer with hammer technique (Fig. 1B; Supplementary Table 1). These cores targeted the youngest Kienbergwand mass transport deposits (MTDs) discovered during seismic data processing (Section 4.2.1).

\subsection{Sedimentological core analyses}

\subsubsection{Multi-sensor core logging and lithological description}

The physical properties of the sediments were determined by a Geotek Multi-Sensor Core Logging (MSCL) at the Austrian Core Facility for scientific core logging and scanning at the Institute of Geology in Innsbruck. Gamma density, P-wave velocity and magnetic susceptibility were measured at $0.5-\mathrm{cm}$ vertical resolution on the unopened cores, and magnetic susceptibility was re-measured at 2-mm vertical resolution on the opened split cores using a Bartington MS2E point sensor. MSCL measurements and calibrations followed the methods described by Blum (1997). The core halves were photographed using a SmartCIS Imaging System at a resolution of 500 dpi. Sedimentary facies were distinguished by macroscopic visual description (colour after Munsell Color, 2009; grain size; sedimentary structures) and by microscopic smear-slide analyses (following the protocol defined by Schnurrenberger et al., 2003).

\subsubsection{Grain size analysis}

Sieving was carried out on three short cores (Mon201701, Mon2017-02 and Mon2017-05). To obtain a representative sample size, $6 \mathrm{~cm}$ of sediment was combined to form each single sample. The samples were dried overnight at $60^{\circ} \mathrm{C}$ and were then sieved using mesh sizes of $2 \mathrm{~mm}$ and $63 \mu \mathrm{m}$, so gravel, sand and the fine fraction could be distinguished. A laser diffraction particle analyser (Malvern Mastersizer 2000) was used to determine grain size of fine-grained sediments. Measurements were done on bulk sediment at varying intervals (down to $0.2 \mathrm{~cm})$.

\subsubsection{Shear strength analysis}

The undrained shear strength $\left(\mathrm{s}_{\mathrm{u}}\right)$ along the sediment cores was determined immediately after core splitting according to the British Standards Institute's BS1377 (1975) standard, with a Wille Geotechnik free-fall cone penetrometer and applying a cone factor of 0.85 for the used $30^{\circ}$ cone (Wood, 1985). The standard measurement spacing was $6 \mathrm{~cm}$; in the intervals affected by the Kienbergwand MTD, the measurement spacing was reduced to $3 \mathrm{~cm}$.

\subsubsection{Age-depth model}

The most well-laminated sediments in the uppermost part of core Mon2016 allowed varve counting by eye (unaided). Due to sections of poorly preserved lamination, multiple counting only yielded an accuracy of about $\pm 5-10 \%$ (0.5-1 year error for every 10 counted years).
This error was reduced by correlation of core Mon2016 to core Mo 05. For this core, Lauterbach et al. (2011), Swierczynski (2012) and Andersen et al. (2017) established a Holocene varve chronology by varve counting on thin sections, Accelerated Mass Spectrometry (AMS) radiocarbon dating and $\delta^{18} \mathrm{O}$ wiggle matching to Greenland ice cores (Section 5.2). Stratigraphic core-to-core correlation between core Mon2016 and core Mo-05 was carried out using high-resolution core pictures. The correlation is based on matching the colour and thickness of prominent layers.

To constrain the ages of the sediments cored offshore from the Kienbergwand, stratigraphic correlation with prominent marker layers in cores Mon2016 and Mo-05 was validated by three new Accelerated Mass Spectrometry (AMS) radiocarbon dates (LARA Laboratory of the University of Bern, Switzerland). Dating was carried out on determined macro-remains from terrestrial plants, and AMS radiocarbon ages were calibrated using the calibration curve IntCal13 (Reimer et al., 2013).

\section{Results}

\subsection{Sedimentary infill of Lake Mondsee}

\subsubsection{Seismic stratigraphy of Lake Mondsee}

In the northern part of the lake (except for a small window), seismic penetration is limited by acoustic blanking (Fig. 2). In the southern part, the shallow areas and the vicinity of the Kienbach delta show acoustic blanking as well. Acoustic blanking is typical for sedimentary units containing (biogenic) gas (e.g. Cukur et al., 2013). These units show a high-amplitude reflection and total wipeout of seismic data (Figs. 2, 3E). In the deep basin, however, the reflection seismic profiles revealed up to $61.5 \mathrm{~m}$ of sedimentary infill in Lake Mondsee (Fig. 3A). In these areas, the acoustic basement and four seismic units were distinguished. The acoustic basement shows from one to several high-amplitude reflections. Below its boundary, no coherent seismic data can be retrieved. It is overlain by acoustically stratified sediment, divided into four seismic units and one sub-unit (Fig. 2). The units 1 to 4 are listed from bottom to top.

Unit 1: It is transparent at its base, gradually changing to a chaotic seismic facies. It is present only at the northern part of the southern sub-basin (Auhof-Bay; Figs. 3B, $C$, and F). It rests against the acoustic basement, which probably consists of bedrock in this area, as suggested by Flysch slopes, west and east of the bay. Its maximum thickness is about $15 \mathrm{~m}$ at the northern shoreline, thinning out towards the basin. Its upper boundary consists of a clear unconformity marked by onlapping seismic units 2, 3, 3b and 4. Unit 1 is the source of widespread vertical narrow low-amplitude features, which indicate dewatering (e.g. Moernaut et al., 2009) and partly alter the appearance of the overlying units (Fig. 3C).

Unit 2: Penetration in this unit (commencing from approximately $35 \mathrm{~m}$ below lake floor (blf)) was limited to 


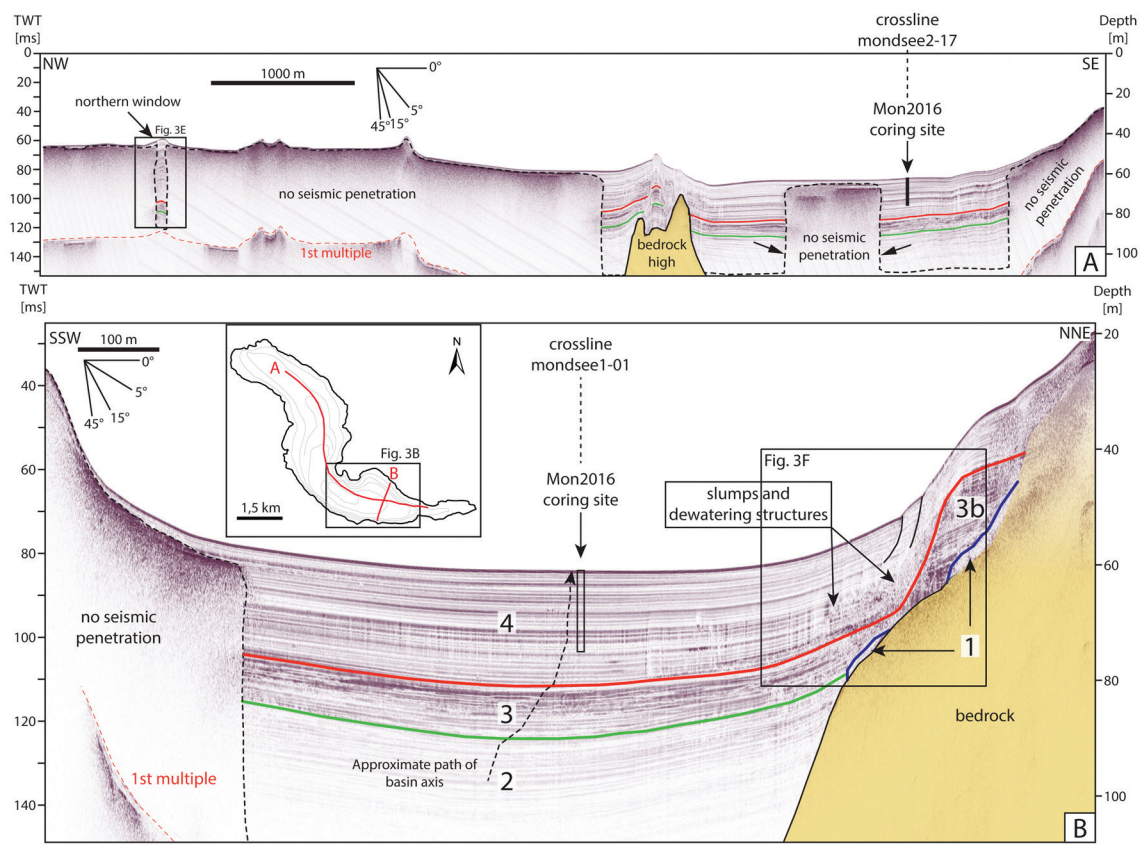

Figure 2: Reflection seismic profiles of Lake Mondsee (Salzkammergut, Austria), showing general seismic stratigraphy. Blue line indicates the transition of seismic Unit 1 to the overlying units. Green line indicates the transition from Unit 2 to Unit 3. Red line indicates the upper border of Unit 3 or Unit 3b. A: Longitudinal section (line mondsee1-01) along the lake axis. Note that seismic penetration is limited to the southern sub-basin. The interval showing higher seismic amplitudes in the northern window is interpreted as the northern continuation of seismic Unit 3 (see Figure 3E). B: Section perpendicular to the lake axis (line mondsee2-17) and outline of subsequent zoomed figure 3F). See inset for locations of seismic lines.

the uppermost 20-25 m (Fig. 2B). It cannot be traced to its bottom because of (1) the interference with lake floor reflection multiples and (2) the attenuation of the seismic wave energy within Unit 2 in the central part of the lake basin. The widely spaced continuous reflections are of intermediate to very low amplitudes and reach from the southern into the northern basin of Lake Mondsee. The reflection pattern in the central part of the basin shows a ponding geometry (indicated by arrows in Fig. 2A). An initially more pronounced basin depression is filled by ponding sediment infill within seismic Unit 2. The reflections terminate in onlap onto the acoustic basement. Unit 2 is conformably overlain by Unit 3.

Unit 3: It is about 4-10-m thick (upper limit ca. $20 \mathrm{~m}$ blf) in the basin. Unit 3 narrows from east to west and from south to north in the vicinity of the current-day Kienbach delta. It shows closely spaced reflections of highly varying lateral continuity and amplitude, with some erosional truncations (Fig. 3D). In the northern part of the southern basin, the reflections are generally more continuous and less chaotic than in the south. In the northern basin, a similar seismic facies can be seen in the small seismic window (see Figs. 2A, 3C). Based on their very similar acoustic reflection characteristics and comparable seismic stratigraphic succession, a stratigraphic correlation to the northern basin can be proposed.

Unit 3b: It is present only at the northern part of the southern sub-basin (Auhof-Bay, see locations in Fig. 1; Supplementary Fig. 2) and near Mooswinkl Bay (Figs. $3 \mathrm{~B}, 3 \mathrm{C}$ and $3 \mathrm{~F})$. Here, bedrock morphology shows a slight shoulder on which Unit $3 b$ was deposited. Unit 3b shows similar seismic facies as Unit 3: closely spaced high-amplitude reflections. The erosional truncations, however, are missing. The parallel reflections dip towards the basin at a low angle and are separated from the basinal part by chaotic seismic facies, the landward boundary of which crosscuts older strata (Fig. 3F). This indicates slumping of Unit $3 \mathrm{~b}$ and disturbance through dewatering of the underlying deposits of Unit 1. The stratigraphic position of the resulting MTDs, however, is not entirely clear: in the northern part of AuhofBay, Unit 3 seems to be onlapping onto the MTDs originating from Unit 3b, whereas MTDs are downlapping onto Unit 3 in the southern part of Auhof-Bay, probably indicating multi-stage mass transport deposit within Unit 3.

Unit 4: It comprises the uppermost $20 \mathrm{~m}$ of sediment infill in the basinal part of Lake Mondsee and drapes Unit 3 across the entire lake basin. The relationship of Unit 4 with Unit 3b changes with the absence or presence of underlying MTDs. Where MTDs are present, Unit 4 terminates in an onlap structure onto the MTDs. In areas without MTDs, Unit 4 conformably overlies Unit 3b. Overall, Unit 4 shows continuous reflections of widely spaced (intermediate to high) amplitudes, which tend to increase towards the lake basin. Laterally confined and very narrow areas showing transparent- to low-amplitude reflections are a common feature of Unit 4. The base of these columnar patches either lies in the underlying MTDs or reaches into seismic Unit 3 itself. These areas are interpreted as fluid escape (dewatering) structures (e.g. Fig. 3F).

\subsubsection{Late Glacial to Holocene lithostratigraphy}

The sedimentary infill of Lake Mondsee cored in Mon2016 is composed of five lithostratigraphic units, labelled lithozones I-V (from base to top; in analogy to Lauterbach et al., 2011, described in core Mo-05), of which lithozone $V$ can be subdivided into several lithotypes (Fig. 4). These can be distinguished both macroand microscopically based on their colour, the amount and thickness of the detrital layers, the amount of organic material and the quantity of authigenic calcite.

Lithozone I $(1376-1250 \mathrm{~cm})$ consists of dense grey (Munsell colour $5 Y$ 6/1) sediment composed of detrital carbonates and occasional thick (up to $7 \mathrm{~cm}$ ) calcitic turbidites. There are abundant intercalated yellowish (5Y 5/2) detrital layers (poorly sorted medium-sized silt) and light grey layers (5Y 7/1) made up of sandy to silty 

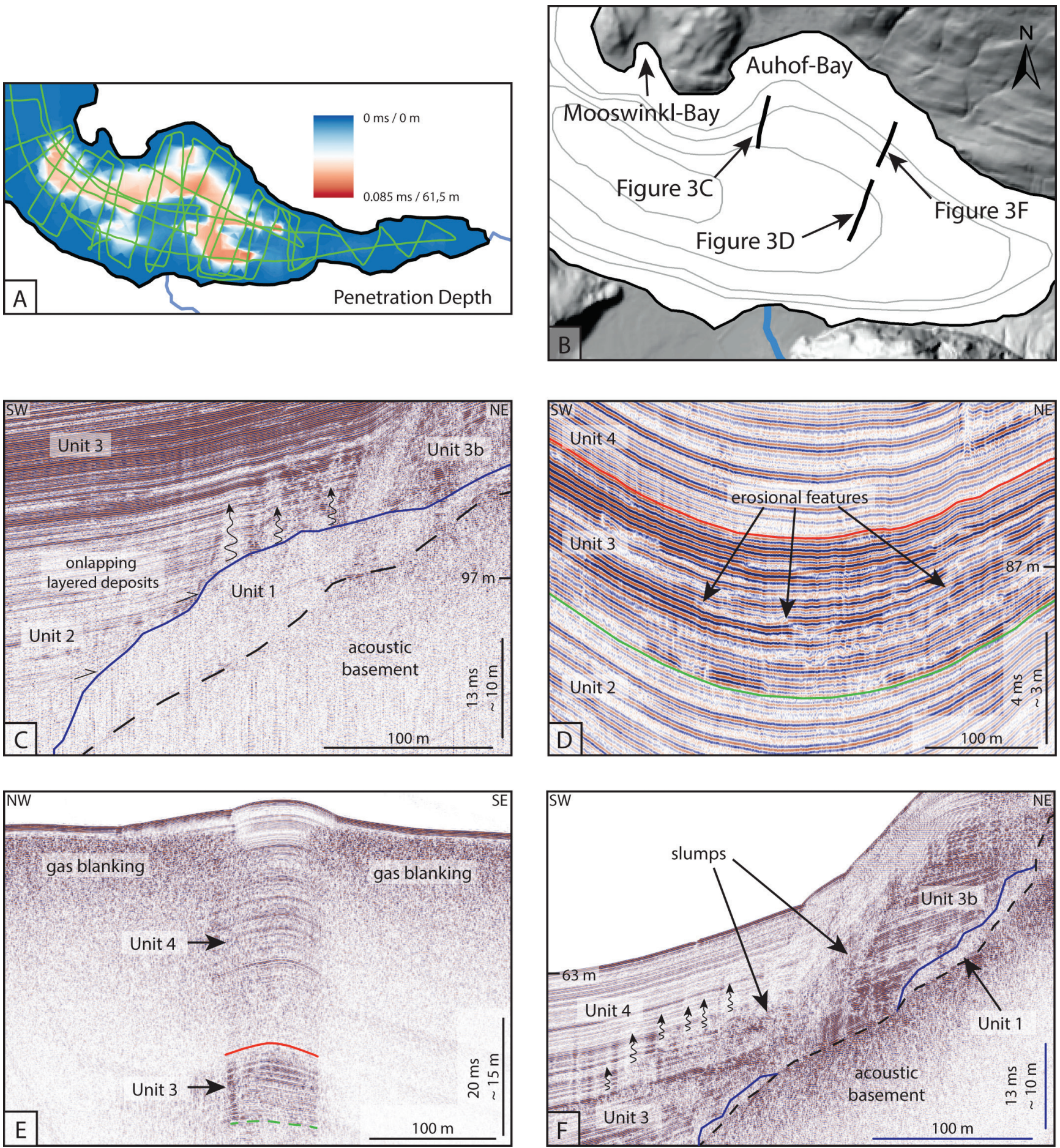

Figure 3: Details of seismic facies and stratigraphy of Lake Mondsee (Salzkammergut, Austria). See fig. 1A, 2A/B for location. A) Penetration depth of 3.5-kHz seismic signal in two-way travel time (TWT) in the southern part of Lake Mondsee. Penetration depth is defined as the depth from which interpretable seismic data can be retrieved. Note that areas showing good penetration are limited to the deeper basin. B) Locations of seismic profiles. C) Fluid escape features (wiggled arrows) originating in semi-transparent seismic Unit 1. Low-amplitude Unit 2 is onlapping onto Unit 1 and overlain by Unit 3, showing high reflection amplitudes. D) Erosional features and lateral variability of reflection amplitudes in seismic Unit 3. E) Gas blanking severely limits seismic penetration in the northern basin. However, Unit 3 and Unit 4 can still be distinguished in a small window. F) Fluid escape features (indicated by wiggled arrows) originating in slump deposits, which separate Unit 3b laterally from Unit 4.

siliciclastics and aggregated carbonate mud. Density ranges from about $1.8 \mathrm{~g} / \mathrm{cm}^{3}$ to nearly $2 \mathrm{~g} / \mathrm{cm}^{3}$. Magnetic susceptibility (MS) fluctuates between $4 \times 10^{-5} \mathrm{SI}$ (light grey layers) and $11 \times 10^{-5} \mathrm{SI}$ (intervals of abundant yellowish layers). The transition from lithozone I to lithozone II
$(1250-1170 \mathrm{~cm})$ is characterised by the first appearance of authigenic carbonate (compare Lauterbach et al., 2011). Authigenic carbonate (appearing as regular rhombs, up to $30 \mu \mathrm{m}$ ) can be easily distinguished from detrital carbonate (pitted and irregularly shaped grains, 


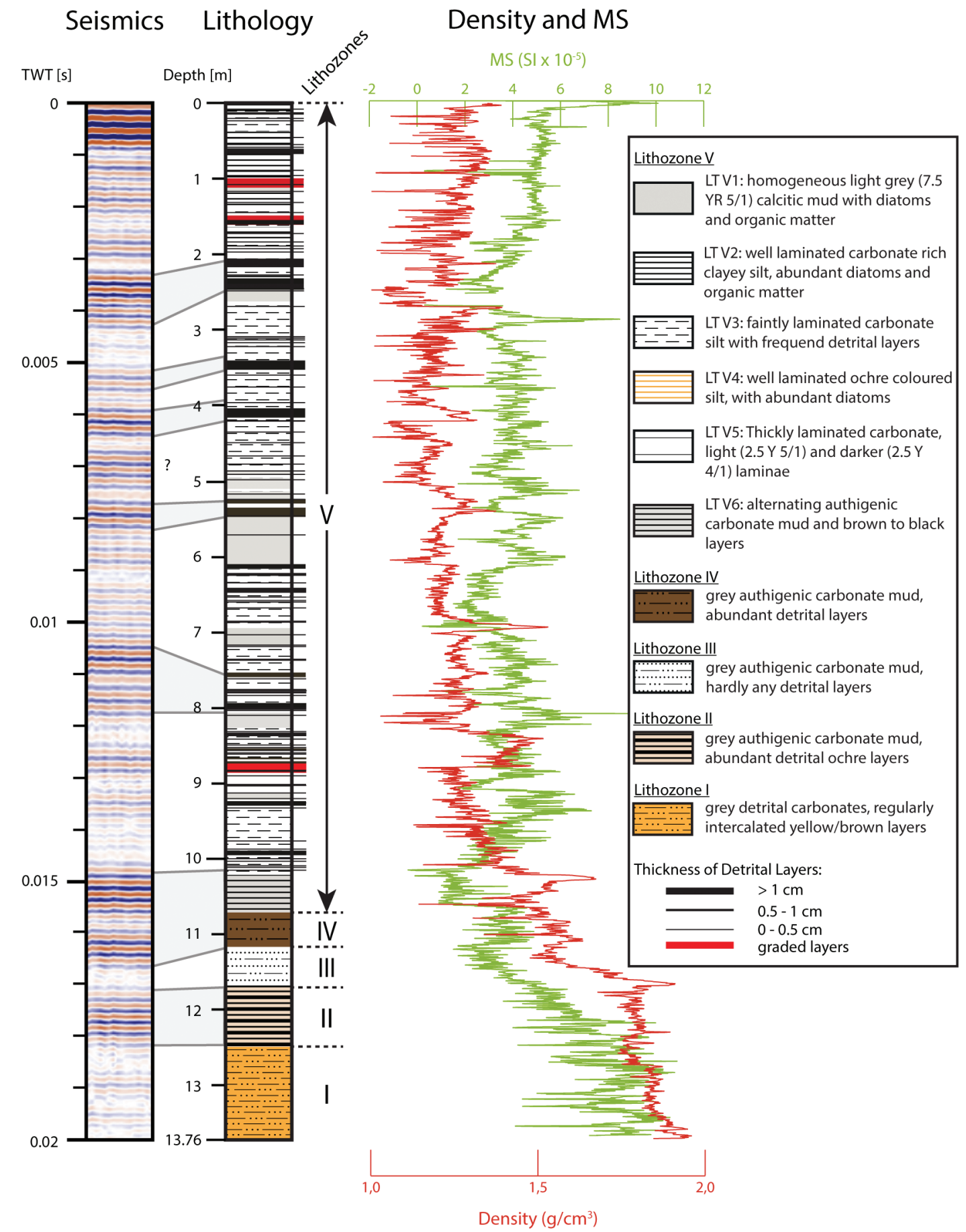

Figure 4: Seismic to core correlation of core Mon2016 from Lake Mondsee (Salzkammergut, Austria; for position see Fig. 2). Grey areas indicate the correlation between high-amplitude reflective zones and flood layer thickness/frequency. Note that distinctive detrital layers are shown only for lithotypes (LT) V1-V5. The other lithotypes and lithozones generally show high frequency of detrital layers, with the exception of lithozone III. TWT: two-way travel time; MS: magnetic susceptibility. Sediment colours according to Munsell Color (2009).

often larger than $50 \mu \mathrm{m}$ ) in smear-slide analysis. The lithological change is reflected in a small drop in density: average values are about $1.85 \mathrm{~g} / \mathrm{cm}^{3}$ in lithozone I vs. $1.75 \mathrm{~g} / \mathrm{cm}^{3}$ in lithozone II.

Lithozone II shows regular dark grey $(5 \mathrm{Y} 6 / 1)$ to light grey $(5 Y 7 / 1)$ and yellowish (5Y 5/2) layer triplets. Ochre-coloured detrital layers (consisting of detrital sandy silt, some siliciclastics present) are still abundant in lithozone II. Large turbidites as seen in lithozone I, however, are missing. Density ranges from 1.72 to $1.9 \mathrm{~g} /$ $\mathrm{cm}^{3}$. As in lithozone I, light grey layers exhibit the lowest MS values (around $4 \times 10^{-5} \mathrm{SI}$ ), and the yellowish layers show peak values of about $10 \times 10^{-5} \mathrm{SI}$. Generally, MS values steadily decrease towards the top of lithozone II, reflecting decreasing detrital input.

Lithozone III (1170-1115 cm) consists of light grey authigenic silty carbonates with interspersed clays, where detrital layers are barely present. The vast majority of 
the sediment is made up of authigenic micritic carbonate with little to no detrital grains. In lithozone III, density decreases drastically to average values of $1.5 \mathrm{~g} / \mathrm{cm}^{3}$. The decreasing trend of MS values in lithozone II continues in lithozone III, reaching values as low as $2 \times 10^{-5} \mathrm{SI}$. Towards lithozone IV $(1115-1071 \mathrm{~cm})$, this changes suddenly: magnetic susceptibility shows average values of $4 \times 10^{-5} \mathrm{SI}$. Frequent detrital layers interrupt the continuous sedimentation of grey laminated lake marl. This marl mostly consists of authigenic carbonates (clay to silt size); however, some detrital carbonates and siliciclastics are present as well. The detrital layers comprise silty detrital carbonates, some siliciclastics and little organic material. Density shows a similar pattern as MS, reaching higher values ( $1.6 \mathrm{~g} / \mathrm{cm}^{3}$ on average) than in lithozone III. The transition from lithozone IV to lithozone $\mathrm{V}$ is marked by a sudden decrease in magnetic susceptibility: the values drop to an average of $1.5 \times 10^{-5} \mathrm{SI}$ at the beginning of lithozone V. This represents the overall minimum of MS in the Mon2016 composite core. Density slightly increases for a short interval at the transition to lithozone V. The overall decreasing trend, however, continues.

Lithozone $\mathrm{V}(1071-0 \mathrm{~cm})$ is composed of well to faintly laminated sediment with abundant organic material and intervals of high detrital input (distinct brown layers). Lithozone $\mathrm{V}$ can be subdivided into several lithotypes (LT V1-V6) based on lamination, colour and organic content. LT V1 comprises non-laminated light grey authigenic carbonate with abundant diatoms and intercalated detrital layers. LT V2 is similar in content to LT V1, but shows a distinct lamination with laminae of about $1 \mathrm{~mm}$ thickness. Sediment microfacies and ${ }^{137} \mathrm{Cs}$ dating carried out by Lauterbach et al. (2011) proved the annual characteristics of the lamination. The distinct lamination of LT V2 allows varve counting. LT V3 consists of faintly laminated grey carbonate-rich clayey silt; varve counting is difficult but possible in some intervals of LT V3. LT V4 is limited to a small interval at the top of the long and short sediment cores. It is represented by well-laminated (1-2 $\mathrm{mm}$ ) yellow brownish carbonate-rich clayey silt and is probably related to an eutrophication period from the 1960s to the early 1980s (Schmidt, 1991). LT V5 is composed of thickly (up to $1 \mathrm{~cm}$ ) laminated grey silty carbonate mud with almost no detrital input. LT V6, the lowermost part of lithozone $\mathrm{V}$, consists of well-laminated ochre-coloured carbonate-rich clayey silt with abundant diatoms. Density is relatively stable (around $1.2 \mathrm{~g} / \mathrm{cm}^{3}$ ) in lithozone $\mathrm{V}$ (Fig. 4). Magnetic susceptibility of lithozone $V$ ranges from $2 \times 10^{-5} \mathrm{SI}$ to about $10 \times 10^{-5} \mathrm{SI}$, with an average of about $5 \times 10^{-5} \mathrm{SI}$. Detrital layers generally correspond to minima of magnetic susceptibility.

\subsubsection{Seismic-to-core correlation}

Core Mon2016 approximately penetrates the upper 3/4 of seismic Unit 4 (Fig. 2B). Comparison of seismic data with lithostratigraphy and gamma-ray density of the composite core reveals that high-amplitude reflections are mainly linked to thick detrital layers (> $1 \mathrm{~cm})$. Intervals of high detrital input are reflected in the MSCL data as sections of high density and low magnetic susceptibility. Intervals of frequent, but thinner $(<1 \mathrm{~cm})$ detrital layers yield medium amplitude reflections, whereas intervals of no to very few detrital layers show low-amplitude reflections (Fig. 4).

\subsection{Kienbergwand Mass Transport Deposit (MTD) data}

\subsubsection{Seismic survey}

In the south-eastern part of the lake, near the Kienbergwand cliff, the reflection seismic data along and across the foot of the slope show a thin (max. $1.8 \mathrm{~ms}$ or ca. $1.5 \mathrm{~m}$ ) laterally confined body with a chaotic seismic facies and a hummocky surface, terminating in the deep basin (Fig. 5A). These are typical seismic attributes and geometries of MTDs (e.g. Mulder and Cochonat, 1996). The MTD has its source area in the south (near the Kienbergwand cliff, therefore hereafter mostly called Kienbergwand Mass Transport Deposit or Kienbergwand MTD) and is covered by approximately $1 \mathrm{~m}$ of wellstratified sediment. In a west-east section, the MTD extends for over $240 \mathrm{~m}$, clearly wedging out in the west and east (Fig. 5B). The MTD can be subdivided into two bodies (western body: $80 \mathrm{~m}$ wide; eastern body: $50 \mathrm{~m}$ wide), connected by a thinner (ca. 1 milliseconds) central part. These bodies define the lake floor morphology in this area. The MTD is characterised by two types of seismic facies: the lower part (shaded darker blue in Fig. 5B) consists of partly continuous high-amplitude reflections. These reflections are cut and overlain by a chaotic, intermediate amplitude seismic facies, in both the central western and eastern body. In between the bodies, the thickness of this seismic facies is strongly reduced. In the downslope direction, the MTD can be traced over a horizontal distance of about 280 m (Fig. 5A). Closer than 150 $\mathrm{m}$ to the shoreline (where slope angles are $>10^{\circ}$ ), seismic penetration and resolution does not allow mapping of the MTD. At the toe of the mass movement, gas blanking occurs precisely to the point where the moving mass ran out onto the basinal flat. In the transversal section (west to east), acoustic blanking is also present directly below the Kienbergwand MTD, severely affecting seismic penetration in this area. Volumetric analysis of the MTD revealed a volume of about $47,500 \mathrm{~m}^{3}$, covering an area of $45,300 \mathrm{~m}^{2}$.

However, the Kienbergwand MTD is not the only irregularity in the seismic data near the Kienbergwand. Although most of the seismic data in this area are subject to gas blanking, at least two stratigraphic levels with distinct acoustic facies and reflection geometries can be identified. These occur in about 85 and 88 ms TWT depth and comprise high-amplitude reflections (Fig. 5B) with irregular surfaces and roughly wedge-shaped lateral geometries. Towards the west, at least the lower seismic horizon clearly shows decreasing amplitudes, suggesting 


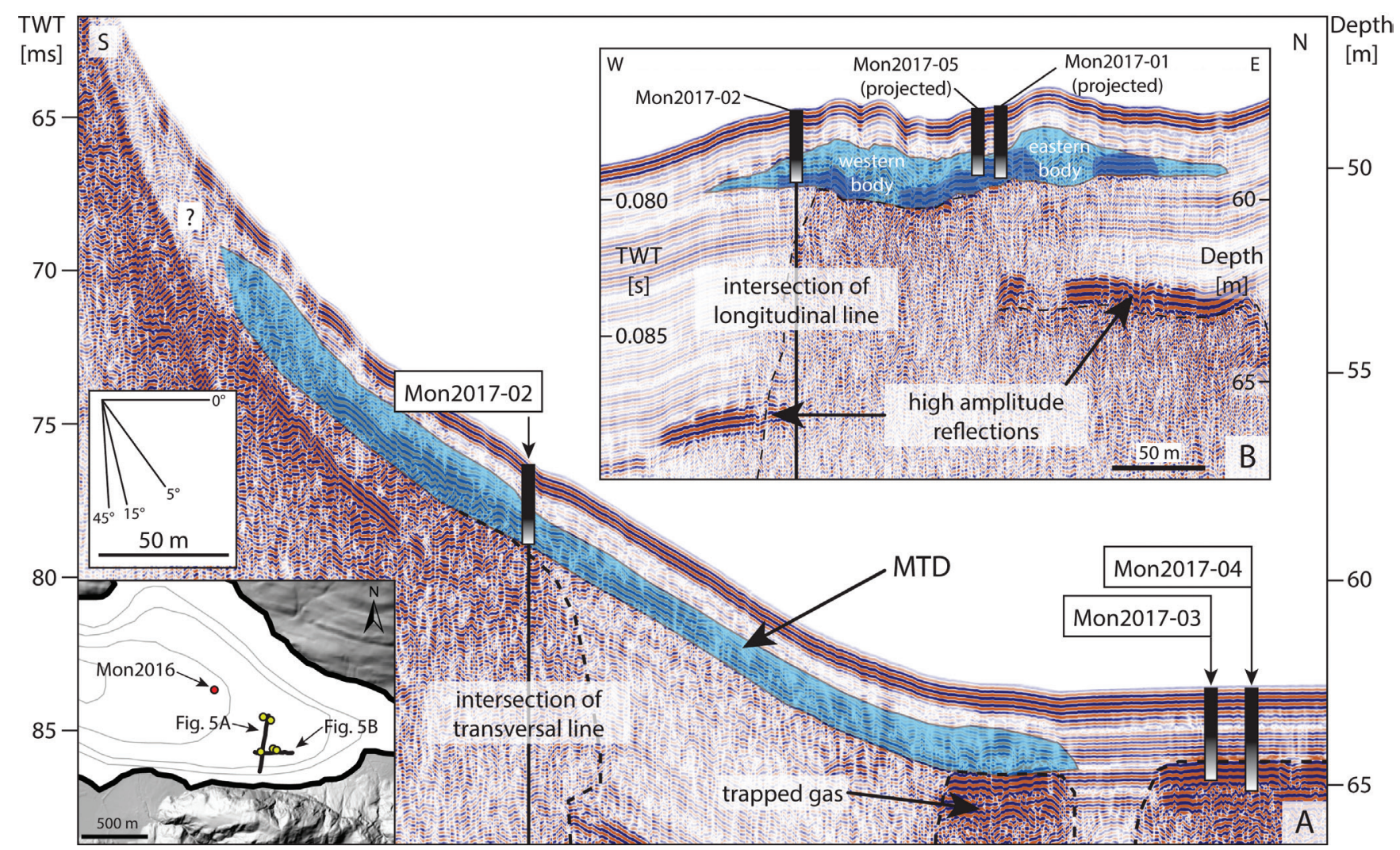

Figure 5: Seismic profiles showing Kienbergwand MTD (SE Lake Mondsee, Salzkammergut, Austria). A: Longitudinal section through the Kienbergwand MTD. B: Transversal section. Note the two different types of seismic facies visible in the MTD. Grading from black to white in the depiction of short cores indicates the uncertainty of the time-to-depth conversion.

that the source of higher impedance material was derived from the Kienbergwand. The susceptive intervals extend below the Kienbergwand MTD, into an area where their larger-scale geometries and internal reflection characteristic cannot be closely constrained due to gas blanking. Nevertheless, according to the distinct seismic facies characteristic, MTDs are interpreted at the respective stratigraphic levels, which correspond to the middle part of seismic Unit 4 and correlate with core Mon2016 at approximately a stratigraphic level of lithozone IV.

\subsubsection{Proximal short cores}

The proximal short cores, Mon2017-01 (Fig. 6), Mon2017-02 (Fig. 7) and Mon2017-05 (Fig. 8), taken 250 $\mathrm{m}$ from the southern shore in front of the Kienbergwand, target the Kienbergwand MTD. Mon2017-02 $(116 \mathrm{~cm})$ was retrieved at the western end of the MTD in a water depth of $57 \mathrm{~m}$, and Mon2017-01 $(111 \mathrm{~cm})$ and Mon2017$05(94 \mathrm{~cm}$ ) were taken approximately $100 \mathrm{~m}$ further to the east, targeting the central part and the eastern body of the MTD in $57 \mathrm{~m}$ water depth. The uppermost part of all proximal cores consists of lithotypes already described for Core Mon2016. These intervals consist of ochrecoloured, distinctly to faintly laminated sediment (LT V2-V4) and non-laminated carbonate mud, which is rich in diatoms (LT V1). The lithozones and intercalated detrital layers can be correlated among the proximal and distal cores (Fig. 9). The lower part of the cores reveals three additional lithotypes, which are referred to as K1-K3 (due to their vicinity to the Kienbergwand).

Lithotype K1 (56-88 cm in Mon2017-02; $63 \mathrm{~cm}$ - base of core in Mon2017-05; not present in Mon2017-01) consists of gravel-sized angular dolomitic fragments (up to $1 \mathrm{~cm}$ in diameter; $30 \mathrm{wt} \%$ of sediment) in a muddy matrix containing high amounts of organic matter (terrestrial plant macrofossils). Sieving analysis revealed normal grading in both cores Mon2017-02 and Mon2017-05. Intervals of higher gravel content show peaks in density (up to $1.3 \mathrm{~g} / \mathrm{cm}^{3}$ in Mon2017-02, nearly $1.4 \mathrm{~g} / \mathrm{cm}^{3}$ in Mon2017-05) and undrained shear strength (5.5 kPa in Mon2017-02; $9 \mathrm{kPa}$ in Mon2017-05). In some intervals, gravel content is too high for reasonable measurements of shear strength. The high dolomitic input is responsible for relatively low MS values $\left(2 \times 10^{-5} \mathrm{SI}\right)$ compared to lithotypes V1-V4 (4-6 $\left.\times 10^{-5} \mathrm{SI}\right)$. In core Mon2017-05, an interval rich in organic material (plant macro-remains; $85-88 \mathrm{~cm}$ ) separates LT K1 into a lower and upper part. The lower part may correlate with the gravel layer (LT K2) in cores Mon2017-01 and Mon2017-02, although no clast-supported gravel interval is present. Grain size distribution, magnetic susceptibility and undrained shear strength all show a slight increase towards the top of LT K1 in core Mon2017-05, whereas in core Mon2017-02, only MS shows two distinct negative peaks at the top of LT K1. The upper boundary of LT K1 is marked by a graded detrital layer. This layer is overlain by homogeneous lacustrine mud. 


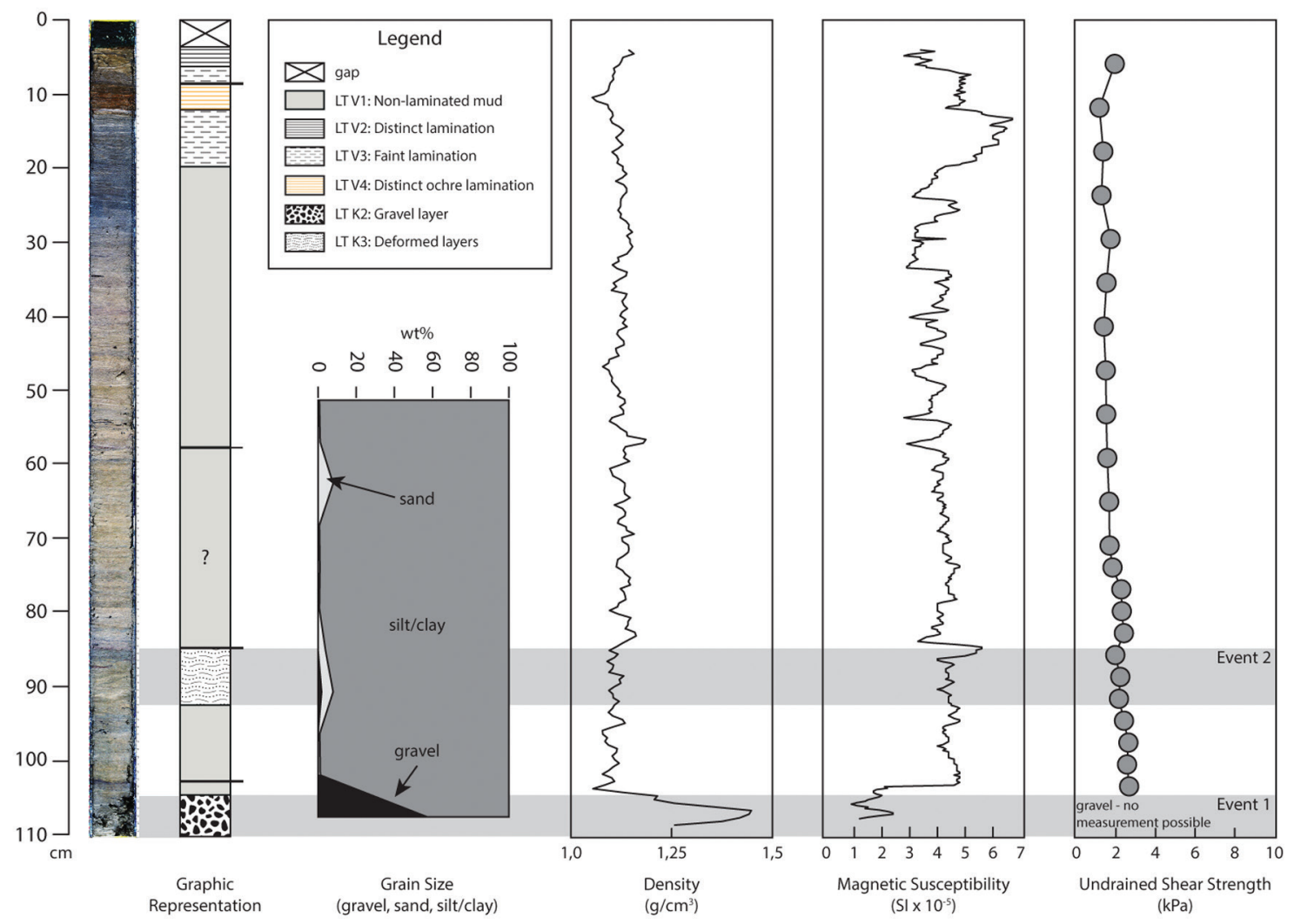

Figure 6: Sedimentological data of core Mon2017-01 from Lake Mondsee (Salzkammergut, Austria).

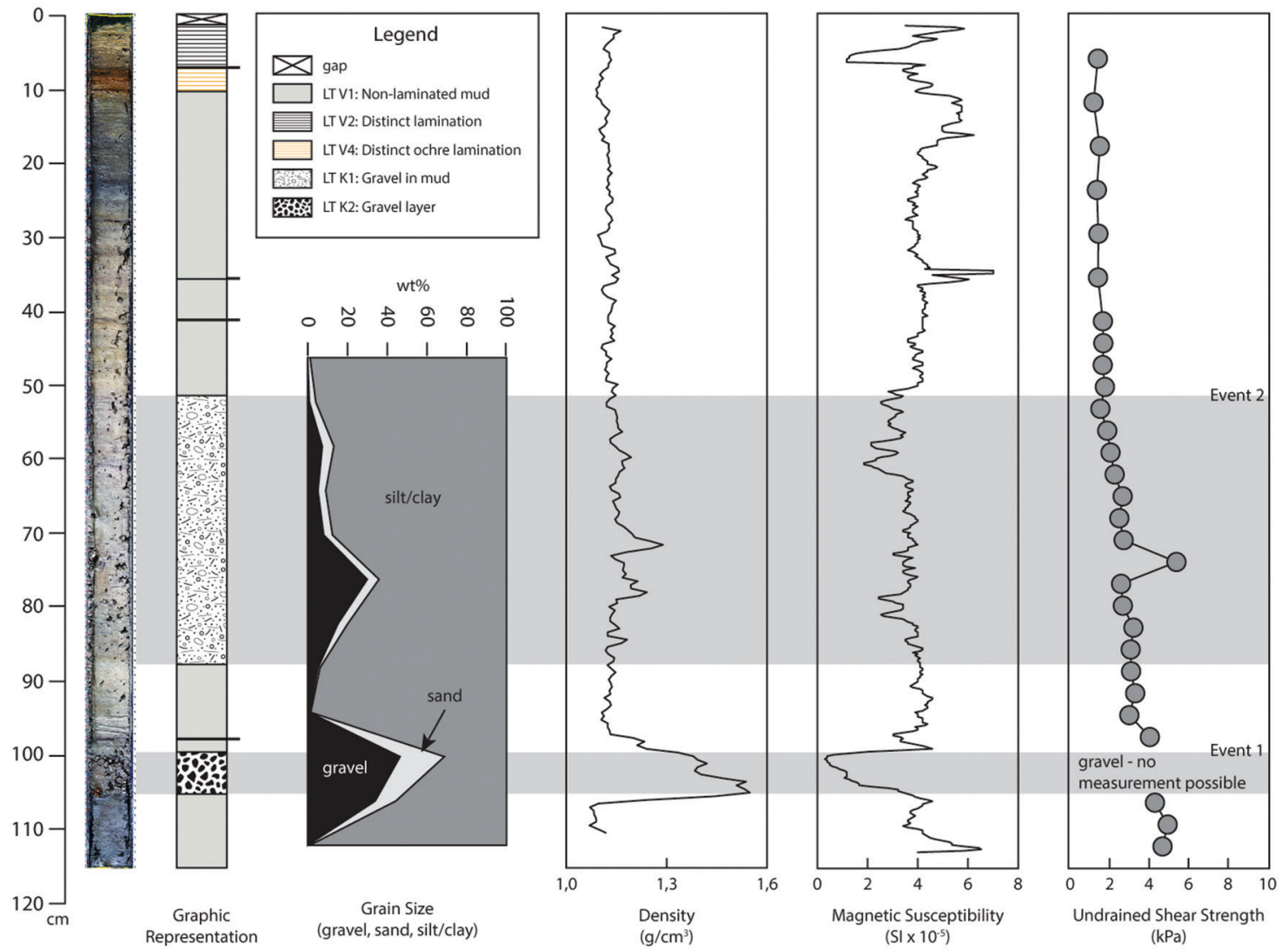

Figure 7: Sedimentological data of core Mon2017-02 from Lake Mondsee (Salzkammergut, Austria). 


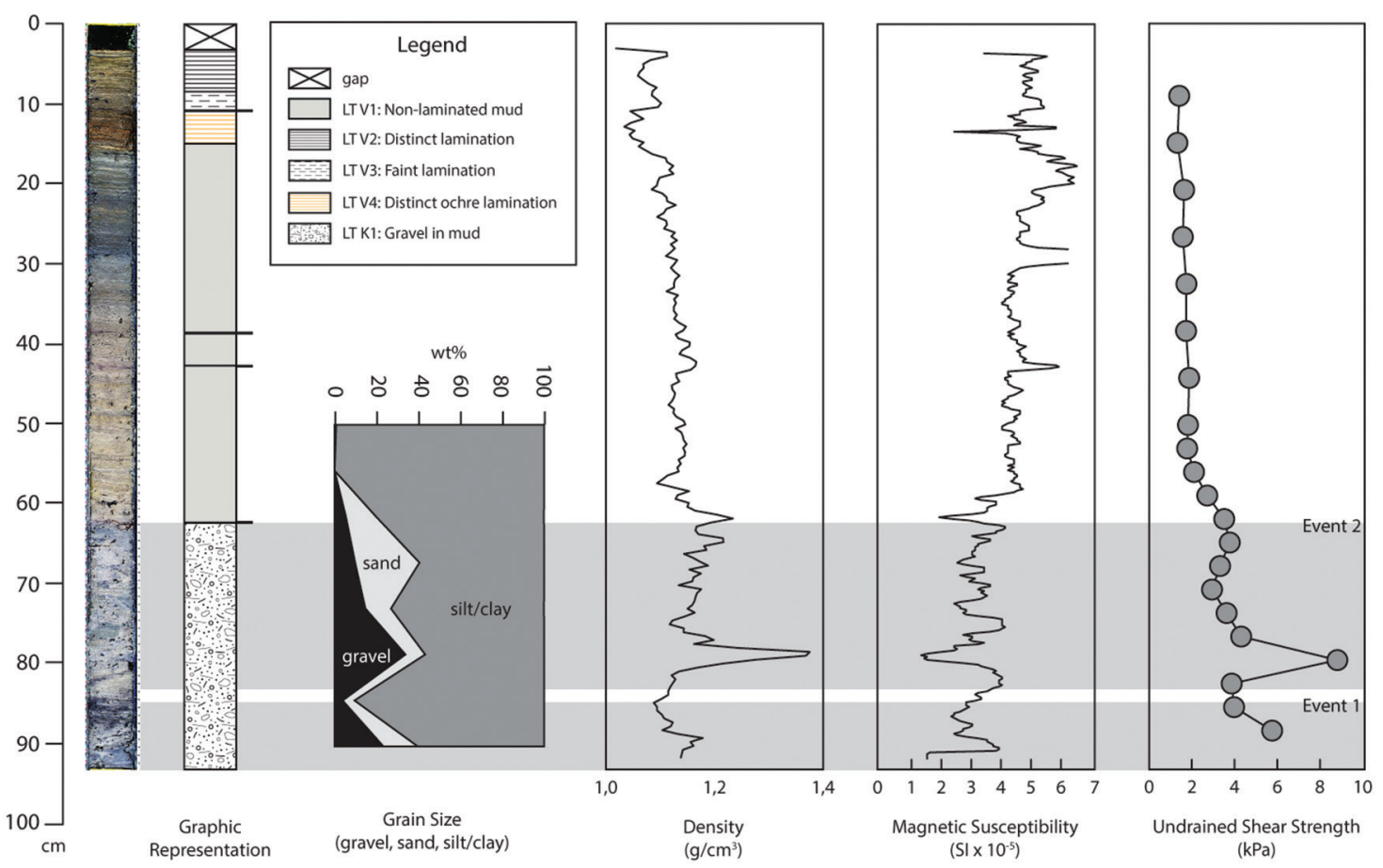

Figure 8: Sedimentological data of core Mon2017-05 from Lake Mondsee (Salzkammergut, Austria).

Lithotype K2 (105 cm - base of core in Mon2017-01; 100-106.5 cm in Mon2017-02; not present in Mon2017$05)$ is characterized by even higher dolomitic gravel (50 wt $\%$ ) and sand ( $20 \mathrm{wt} \%$ ) content and shows a clastsupported fabric in the lower part. The basal gravels have a sharp (erosional?) contact to underlying homogeneous lacustrine mud and show densities of up to $1.55 \mathrm{~g} / \mathrm{cm}^{3}$ and MS values as low as $0.5 \times 10^{-5} \mathrm{SI}$. The upper boundary of LT K2 is an indistinct transition to homogeneous grey mud. This mud is overlain by a graded detrital layer rich in organic matter.

LT K3 is present only in Mon2017-01 $(86-94 \mathrm{~cm})$. It is characterised by deformed layers showing effects of shearing and a slight increase in grain size.

\subsubsection{Distal short cores}

To investigate a potential turbidite layer associated with the Kienbergwand MTD in the deeper basin and to correlate a respective event layer with the long core Mon2016, two short cores labelled Mon2017-03 and Mon2017-04 were taken in the distal part, approximately $500 \mathrm{~m}$ offshore from the Kienbergwand. Mon2016-1_0-1m, Mon2017-03 and Mon2017-04 showed no major differences in terms of general sedimentation patterns (Fig. 9). Well-laminated (LT V2 and LT V4) and faintly laminated (LT V3) sediment alternate and detrital layers are frequent. Macroscopically, two main types of detrital layer can be distinguished: (1) greyish to black (2.5GY 4/2) layers with a sharp base mainly consisting of organic, siliciclastic and carbonate detritus (black arrows in Figs. 9, 10) and (2) brownish (10Y 4/2) slightly graded layers with less organic material but enriched in calcitic and dolomitic fragments (red arrows in Fig. 10). However, a 1.2-cm-thick layer at about $72 \mathrm{~cm}$ depth in both cores Mon2017-03 and Mon2017-04 is distinctly different and consists of a basal brownish part $(0.7 \mathrm{~cm}$; red arrow in Fig. 10) and an upper greyish darker part $(0.5 \mathrm{~cm}$; green arrow in Fig. 10). The lower part of this layer is rich in clastic detrital carbonate grains (up to $150 \mu \mathrm{m}$ ) with little organic content. The darker upper part is rich in organic matter. Grain size analysis showed slightly higher values for the lower part (Fig. 10).

\subsubsection{Core-to-seismic and core-to-core correlation}

The three lithotypes, $\mathrm{K} 1-\mathrm{K} 3$, identified in the proximal cores all are typical sedimentary deposits of gravitational mass transport (e.g. Schnellmann et al., 2006) and are interpreted as linked to the Kienbergwand MTD mapped in about $1 \mathrm{~m}$ subsurface depth in reflection seismic data. Both seismic and core data show that the Kienbergwand MTD is the result of at least two depositional phases. Seismic-to-core correlation of cores Mon2017-01 and Mon2017-05 suggests that the high-amplitude seismic facies corresponds to the gravel layer of LT K2, whereas LT K1 shows chaotic intermediate-amplitude facies.

Core Mon2017-02 clearly reveals that the two depositional phases are separated by continuous deposition of LT V1, thus revealing two mass movement events separated in time. The LT K1 deposits of the younger event are absent in core Mon2017-01 but reveals a stratigraphically correlative sheared interval (LTK3) and overlying indistinct LTV1. This is interpreted to be deformed LTV1 affected by nearby mass movement during the deposition of LT K1; the two respective seismic reflection patterns of which cannot be separated in the seismic data (Fig. 5).

As the dolomite gravels in the proximal cores suggest, the distal sedimentological signature of the 


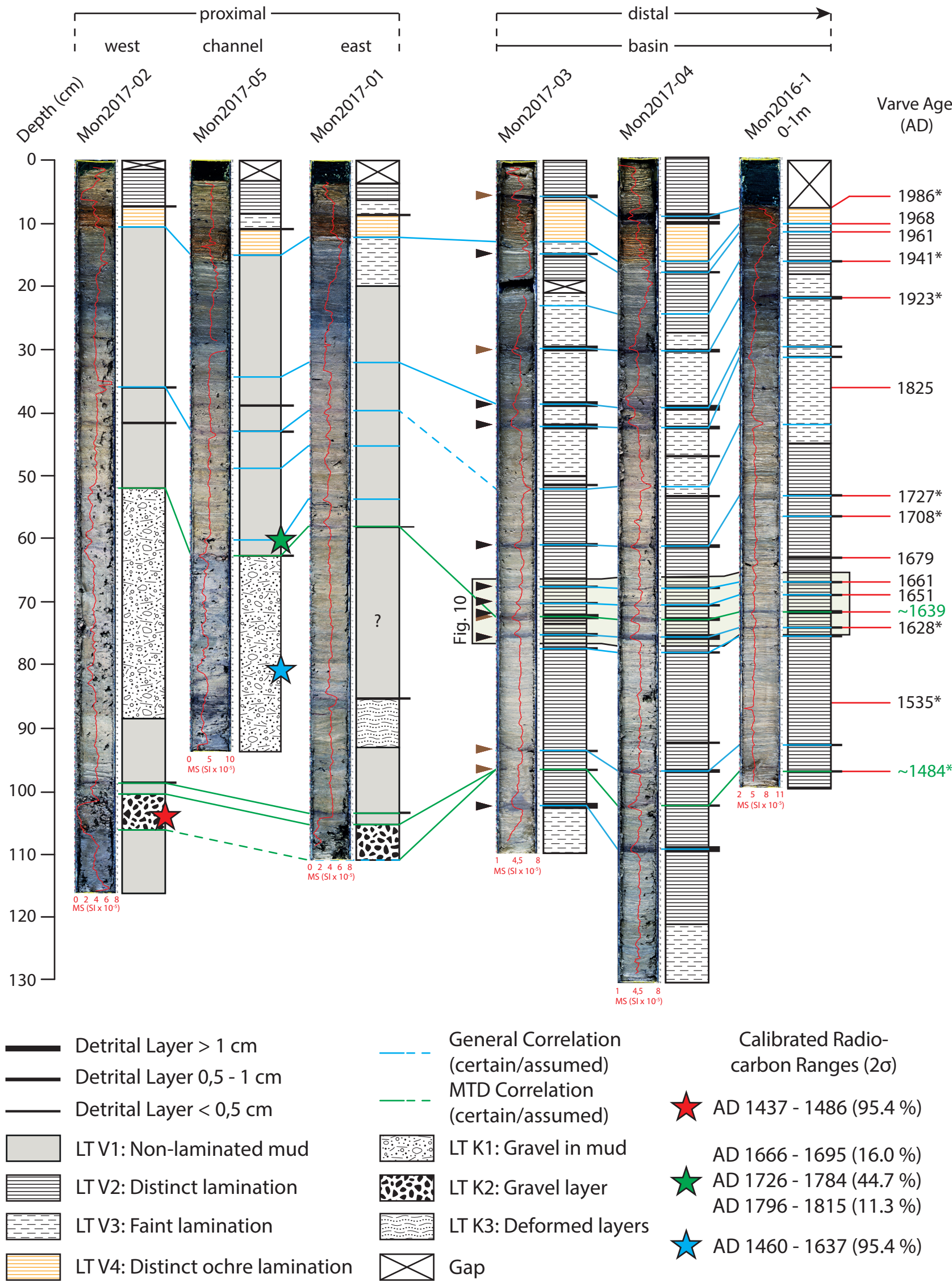

Figure 9: Correlation of short cores and the uppermost section of the long core Mon2016-1 from Lake Mondsee (Salzkammergut, Austria). Correlation of event layers related to the 2 MTD events is highlighted in green. Brown arrows indicate detrital layers enriched in calcitic and dolomitic fragments. Black arrows point out detrital layers consisting of organic, siliciclastic and carbonate detritus. For each core, magnetic susceptibility is plotted. Ages were determined based on varve counting and correlation with the varve-dated core Mo-05 (Lauterbach et al., 2011; Swierczynski, 2012). Radiocarbon ages were calibrated using IntCAL calibration curve (Reimer et al., 2013; see supplementary data for further information). 
Mon2017-03

$66,5-77 \mathrm{~cm}$
Mon2017-04

$66,5-76,5 \mathrm{~cm}$
Mon2016

$66-76 \mathrm{~cm}$
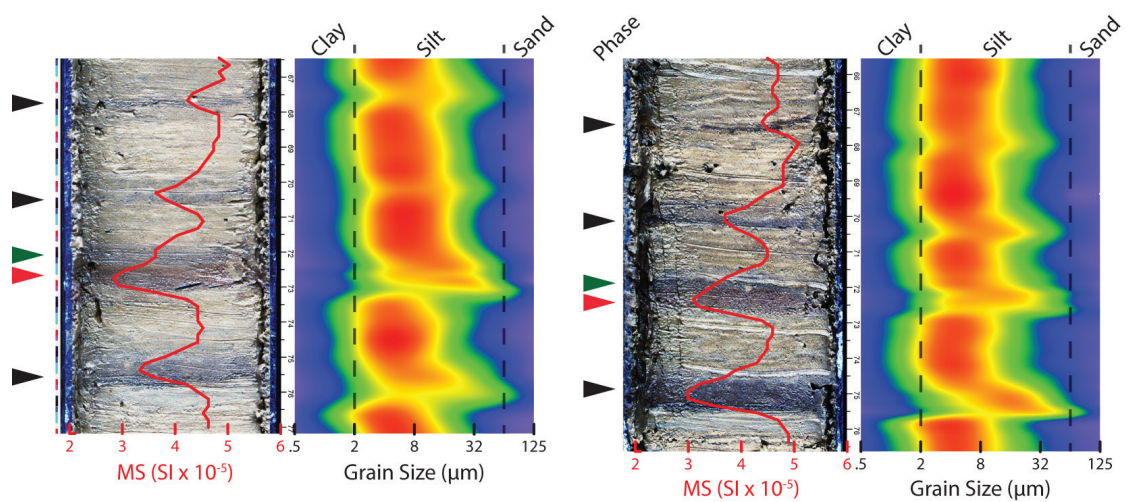

Grain Size $(\mu \mathrm{m})$
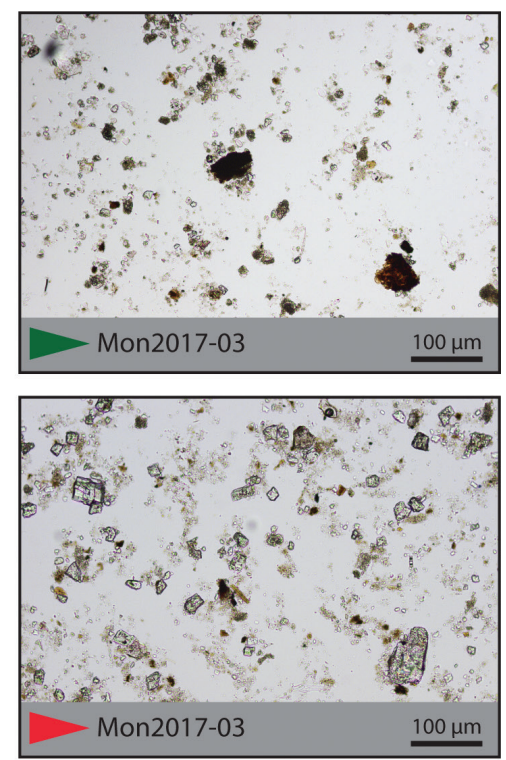
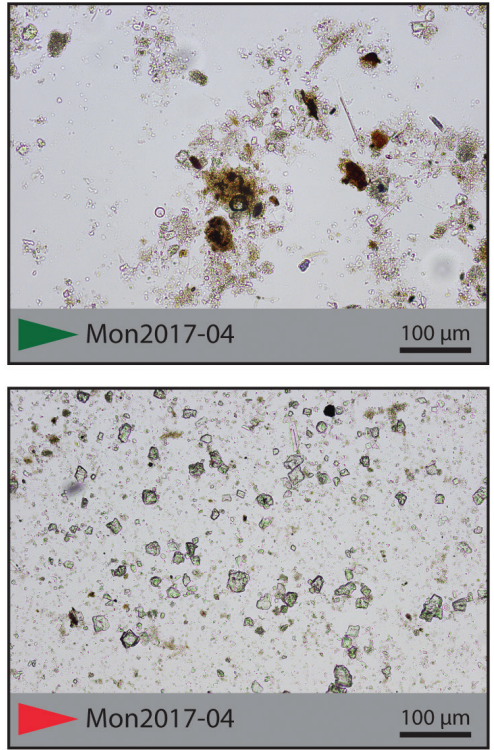

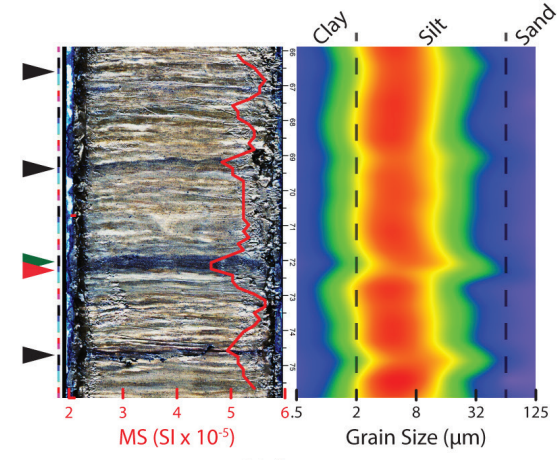

Volume $\%$
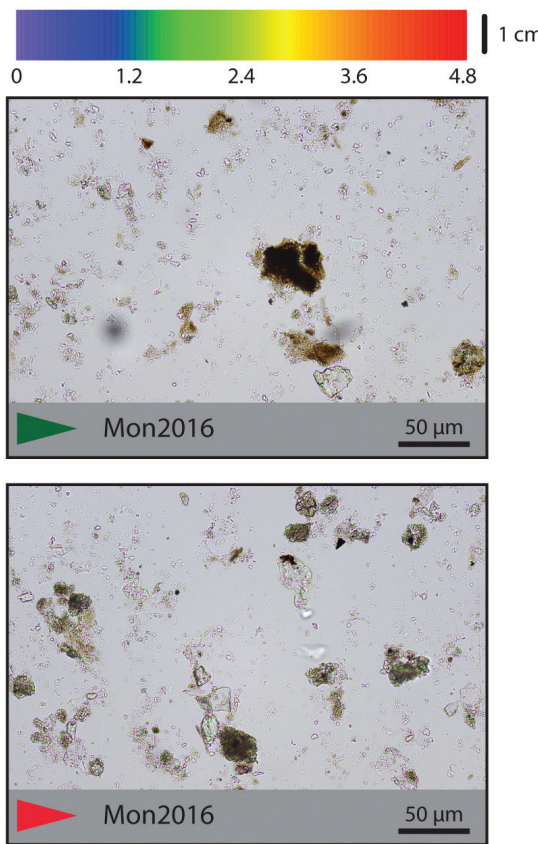

Figure 10: The basinal fingerprint of the younger mass movement event at Lake Mondsee (Salzkammergut, Austria). Four detrital layers are present in the target interval determined by macroscopic core description and magnetic susceptibility. Of these, three could be determined as flood layers (denoted by black arrows), showing significant siliciclastic input. The two-part layer (red and green arrow), consisting of abundant silty to sandy dolomitic detritus, overlain by organic matter, represents the younger event. The two-part nature is confirmed by grain size analysis as well.

Kienbergwand MTD should mainly consist of dolomitic detritus with little organic content. Correlation of proximal and distal cores based on macroscopic appearance, magnetic susceptibility and composition of detrital layers determined by smear-slide analyses (Fig. 9) reveals that the 1.2-cm-thick two-part layer at $72 \mathrm{~cm}$ depth in core Mon2017-03, which contains large clastic detrital carbonate grains with little organic content, is the best candidate for association with Event 2 of the Kienbergwand MTD. This suggests that the fingerprint of LT K1 in the basin is small, yet distinct: the other detrital layers occurring in the stratigraphic succession (as described Section 4.2.3) can be linked to be flood and/or debris flow-related event layers either sourced from the Flysch zone (e.g. via Griesler Ache) or the NCA (via the Kienbach brook) based on their mixed organic composition (either siliciclastic and calcitic or calcitic and dolomitic) with high organic content composition (black and brown arrows in Fig. 9 and 10, respectively; Swierczynski, 2012). In contrast, the event layer from the Kienbergwand MTD, at least in the proximal part, is characterised by a distinct layering of dolomitic clastic grains with little organic content in the lower part, separated from an overlaying part with higher organic content. In cores Mon2016 and Mo-05 (which is most distal), however, the two layers cannot be distinguished anymore and the sedimentation of organic material dominates.

\subsubsection{Dating the Mass Movement Deposits}

The three AMS radiocarbon values from cores Mon201705 and Mon2017-02 provide age estimates for the deposition of LT K1 and LT K2, respectively (Supplementary Table 2, Supplementary Fig. 1). The minimum age of the younger MTD event can only be broadly constrained to AD 1666-1815 (20), because the IntCal13 calibration curve (Reimer et al., 2013) shows a plateau at the ${ }^{14} \mathrm{C}$ age of the 
dated piece of bark (Pinaceae indet.; Mon2017-05_60 cm, i.e. $4 \mathrm{~cm}$ above $L T K 1$ ). The maximum age of this younger event is constrained by a fir (Abies alba) needle fragment dated to AD 1460-1637. Based on the principle of stratigraphic superposition, this age range then also serves as minimum age for the older Kienbergwand MTD. A narrower calibrated age date could be obtained for the respective maximum age from AMS dating of a fir (Abies alba) twig sampled at Mon2017-02_106 cm (i.e. within LT $K 2)=A D$ 1437-1486. To further constrain the age of the Kienbergwand MTDs, the respective event layers were correlated by detailed event layer-by-layer core-to-core correlation with the Mo-05 core which was varve dated by Lauterbach et al. (2011) and Swierczynski (2012). Stratigraphic correlation revealed a varve age of about AD $1639 \pm 5$ years for the younger event, which fell into the same range as the radiocarbon-dated fir needle fragment within the event deposits. For the older event, the respective event layer recorded in core Mon2017-03 was affected by coring disturbance but best-candidate correlation suggested that the layer occurs in $96.5 \mathrm{~cm}$ depth, which can be correlated with Mo-05 (Swierczynski, 2012) to determine an age of about AD $1484 \pm 7$. This varve-correlated age fits very well with the radiocarbon age estimate (AD 1437-1486) of a twig within the event deposits.

\section{Discussion}

\subsection{Seismic stratigraphy of Lake Mondsee}

van Rensbergen et al. (1998) distinguished five main facies units in Lake Annecy (north-western Alps, France), which later were defined as "type stratigraphy" for glacial lakes by some authors (Charlet et al., 2008). The five main facies units consist of (from bottom to top): (1) chaotic to irregularly stratified reflections with irregular external form; (2) a lower basin fill that ponds the axial deep and generally shows no reflections; (3) a divergent onlap fill that ponds the axial deep; (4) a prograding or divergent fill and (5) a low-amplitude sheet drape. These were interpreted as (1) grounding-line deposits related to sub-aqueous meltwater discharge (sub- or proglacial); (2) a glaciolacustrine sediment fill quickly deposited in a proglacial or subglacial lake; (3) lacustrine fans fed by meltwater streams in a proglacial lake; (4) fan deltas in a post-glacial lake and (5) authigenic lacustrine sediments.

In comparison to these units found in perialpine (van Rensbergen et al., 1998, Fiore et al., 2011) and Chilean lakes (Heirman et al., 2011), the seismic units of Lake Mondsee are interpreted as follows: Unit 1, overlying the acoustic basement and showing transparent to chaotic seismic facies, is interpreted as a (Würmian) glacierderived, morainic or ice contact deposit formed by the Traun glacier. Unit 2 consists of mostly continuous low- to intermediate-amplitude reflections with ponding geometries. This suggests deposition by underflows linked to glacial meltwater pulses entering a proglacial paleo-Lake Mondsee (Sturm and Matter, 1978; van Rensbergen et al. 1998).
Unit 3, showing high- to very-low-amplitude reflections and cut-and-fill structures with strong lateral variations, was deposited in a higher-energy environment than seismic Unit 2. In analogy to Charlet et al. (2008), Unit 3 is interpreted as distal lacustrine fan deposits of a proglacial lake. As in Unit 2, the main transport mechanism was underflows, but the cut-and-fill geometries and higher reflection amplitudes indicate erosion and deposition of coarsegrained, sandy sediments. Unit boundaries converging towards the north and the west indicate two separate sediment sources for the southern sub-basin: one near the current-day outflow of Seeache and one near Scharfling. The westwards increasing continuity of reflections indicate dominant meltwater pulses from the east. Unit $3 \mathrm{~b}$, as Unit 3 , shows high-amplitude reflections. These are influenced from dewatering of the underlying seismic Unit 2. Depositional conditions and the stratigraphic position of Unit 3b cannot be constrained by unique seismic interpretations. Thickness of Unit $3 \mathrm{~b}$ and the overlying Unit 4 as well as stratigraphic considerations in the northern part of the Auhof Bay indicate that the deposition of Unit 3b started before Unit 3 was deposited. Following this, a considerable amount of sediment was deposited by interflows (Sturm and Matter, 1978). Underflows would not have reached the bedrock shoulder on which Unit 3b was deposited.

Increasing sediment loading and erosional undercutting during the more dynamic deposition of Unit 3 may have destabilised large portions of the lateral slope, resulting in the observed MTDs and slumps. Repeated creeping and slumping is typical for quick clay-type glaciolacustrine sediments, due to fast deposition and low hydraulic conductivity (Wiemer et al., 2015).

Unit 4, a draping sedimentary unit with intermediateto high-amplitude reflections, is indicative of authigenic sedimentation (van Rensbergen et al., 1998; Charlet et al., 2008). The higher amplitudes hint at increased terrigenous input. Towards the lake margins, sedimentation rates are lower. This is especially pronounced in the Mooswinkl and Auhof Bays: Herrmann (1990) reported that Late Glacial sediments are only covered by $2 \mathrm{~cm}$ of authigenic sediment in Mooswinkl Bay. Herrmann (1990) excluded erosional processes because of lacking erosional discordances and because bedrock ridges protect the sediment from erosional currents in Mooswinkl Bay. Except for the fourth seismostratigraphic unit defined by van Rensbergen et al. (1998), all the typical seismic units are therefore present in Lake Mondsee. This fourth unit, consisting of fan deltas, may be present near the south-eastern shoreline, where seismic penetration is limited by gas blanking.

\subsection{Age of the sedimentary infill of Lake Mondsee}

The core Mon2016 only penetrates the uppermost 13.76 $\mathrm{m}$ of seismic Unit 4. Comparison to the Mo-05 sediment core (Lauterbach et al., 2011) allows for age estimations of the main lithozone boundaries: LT I-LT II: 14,625 cal. a BP; LT II-LT III: 13,500 cal. a BP; LT III-LT IV: 12,500 cal. a BP; LT IV-LT V 11,510 cal. a BP (Fig. 11). Therefore, lithozone V 


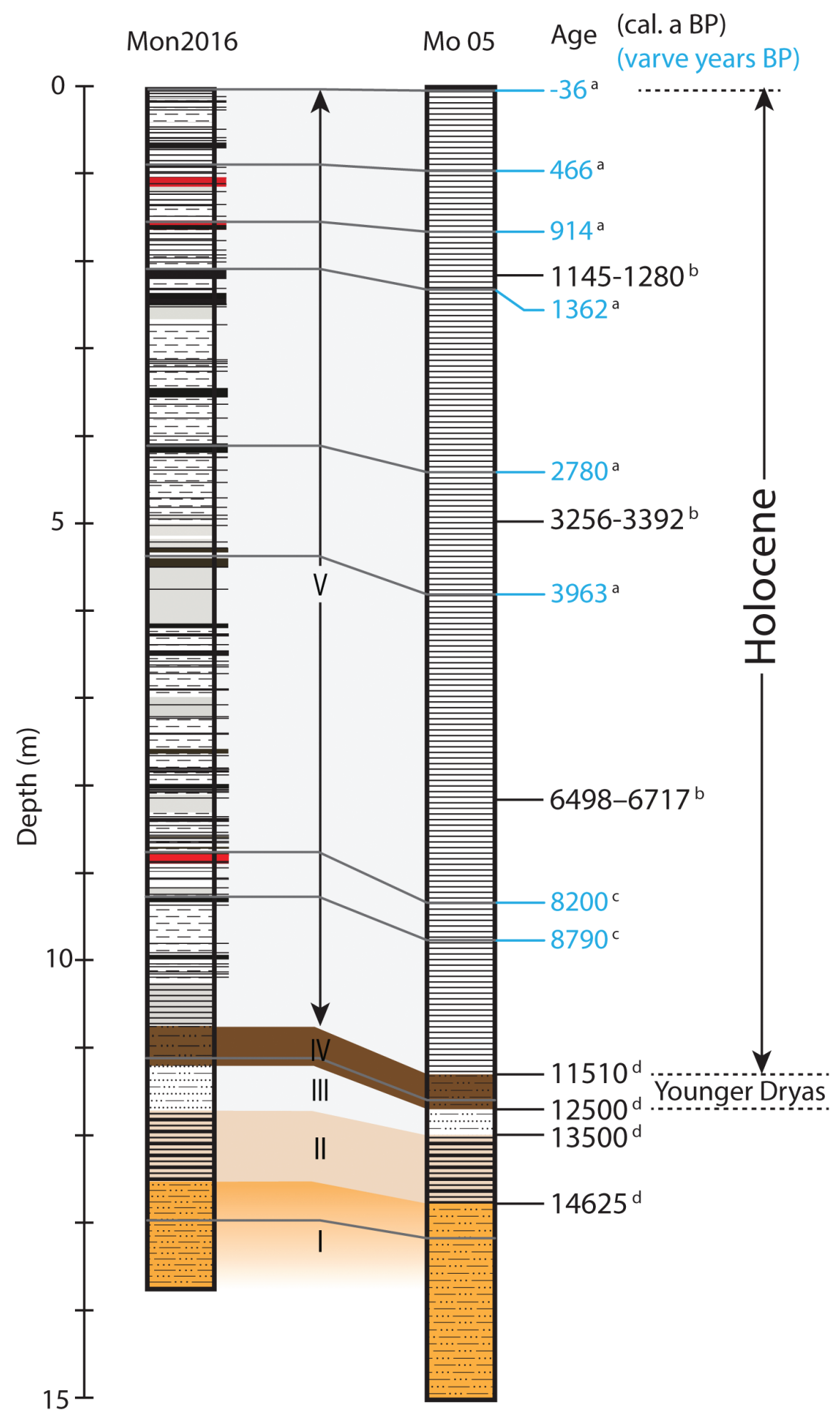

Figure 11: Comparison between the sediment cores, Mon2016 and Mo-05, from Lake Mondsee (Salzkammergut, Austria). Correlation was carried out by comparison of optical images and distinct detrital layers. Ages were defined by the following methods and authors: ${ }^{a}$ varve counting (Swierczynski, 2012); ${ }^{b}$ radiocarbon dating (Lauterbach et al., 2011); c varve counting (Lauterbach et al., 2011); d $\delta^{18} \mathrm{O}$ wiggle matching with Greenland NGRIP ice record. Note that lithozone V corresponds to the Holocene and lithozone IV to the Younger Dryas. Lithozone V of core Mo-05 was not further divided into lithotypes by Lauterbach et al. (2011); detrital layers of core Mo-05 are not plotted.

largely corresponds to the Holocene, whereas lithozone IV is equivalent to the Younger Dryas. Allerød, Older Dryas and Bølling are contained in lithozones III, II and I.
The grey-yellow layer couplets of lithozone I are interpreted by Lauterbach et al. (2011) as depositions of over- (which is unlikely) and interflows, indicative of meltwater pulses in spring. Lauterbach et al. (2011) reported dropstones in lithozone I as well, indicating seasonal ice cover. Baster et al. (2003) for Lake Geneva and Ndiaye et al. (2014) for Lake Neuchâtel (Switzerland) described similar layers; however, these authors considered such layer couplets to have an aeolian origin (Loess-like deposits). To resolve the origin of these layers in core Mon2016, further investigation is needed. Nevertheless, both Lauterbach et al. (2011) and Ndiaye et al. (2014) considered these grey-yellow layer couplets as dating into the Oldest Dryas.

Apart from the uppermost 10-11 m covered by cores Mo-05 and Mon2016, most of the seismically imaged postglacial sedimentary infill of Lake Mondsee (as interpreted from the seismic stratigraphy) was deposited in a rather short time after the retreat of the Traun Glacier. Ice decay after the Last Glacial Maximum (LGM; $20.9 \pm 1.5$ ka; Ivy-Ochs et al., 2008) occurred during a short period from 21,000 to $19,000 \mathrm{BP}$ (Reitner, 2011). Seismic Unit 1 probably was deposited within that time frame. Units 2 and 3 and the lowermost quarter of seismic Unit 4 were deposited between $19,000 \mathrm{BP}$ and 14,625 cal. BP. Assuming higher acoustic velocities of about $1700 \mathrm{~m} / \mathrm{s}$ below 20 mblf, as described by Finckh et al. (1984), at least $55 \mathrm{~m}$ of sediment was accumulated in this period. Mean sedimentation rates were in the order of at least $1.4 \mathrm{~cm}$ per year. Compared to other perialpine lakes (e.g. Lake Geneva: Vernet et al., 1974) and the nearby Lake Traun (Traunsee), which has accumulated more than $350 \mathrm{~m}$ of sediment since the LGM (Burgschwaiger and Schmid, 2001), this would still be only a minor amount. Schneider et al. (1987), who investigated Lake Traunsee with seismic 
methods, reported Late- and Postglacial sediment thicknesses of more than $45 \mathrm{~m}$. Note, however, that the seismic data in Lake Mondsee are only available to a depth of $150 \mathrm{~ms}$ TWT ( $60 \mathrm{~m}$ blf) and the acoustic basement was not reached. Thus, the mean sedimentation rates of at least $1.4 \mathrm{~cm}$ per year for Unit I reported here are only lower minimum rate estimates; actual sedimentation rates may well be higher depending on the real basement depth (which was not imaged by the seismic data). Van Husen (2003) reported a glacial advance filling the basins of Lake Hallstatt, Lake Altaussee, Lake Grundel, Lake Öden and Lake Gosau, at about 16,000 years cal. BP. This event could correspond to the Gschnitz stadial, which according to Ivy-Ochs et al. (2008) has a maximum age of $15,400 \pm 470{ }^{14} \mathrm{C}$ a BP $(18,020-19,100 \mathrm{cal}$. a BP $)$ and a minimum age of $15.4 \pm 1.4 \mathrm{ka}$ (determined by ${ }^{10} \mathrm{Be}$ surface exposure dating). This glacial advance may potentially be related to the deposition of seismic Unit 3, reflecting increased erosion in the hinterland. As described earlier, the stratigraphic position and depositional age of Unit 3b are unclear and require further investigation.

\subsection{Kienbergwand rockfall and lacustrine mass movement processes}

\subsubsection{Emplacement of the Kienbergwand MTDs?}

The resulting deposits from the younger AD 1639 event (LT K2) and the older AD 1484 event (LT K1) that comprise the Kienbergwand MTDs are strikingly different in two points: (1) The gravelly layer of LT K1 is clast supported with little (as low as 30\%) silt and clay content, whereas LT K2 is characterized by a gravel-in-mud facies; (2) The deposits of the older event have a rather planar extension as imaged in reflection seismic data, while geometries resulting from the younger event show channel-levee-type structures, suggesting, respectively, sheettype and channelized flow.

Lithofacies LT K1 shows the characteristics of an intermediate between a cohesive flow and a modified grain flow as described by Lowe (1982). A modified grain flow differs from a grain flow sensu stricto in that the modified grain flow shows an interstitial fluid denser than the ambient fluid. This is the case, if suspended silt and clay is present in between the coarse grains (density-modified grain flow). The dispersion against gravity is then aided by the buoyant effect of the interstitial fluid (Lowe, 1976). These flows advance through the dispersive pressure of continuous grain collisions. For such a movement to occur and be maintained, however, slope angles of about $9^{\circ}$ are necessary for a sediment composition of the kind indicated for LT K2 (Lowe, 1976). In case of the lower Kienbergwand MTD (AD 1484 event), gravels are the main coarse material involved in the process, which may lower the slope angle needed. As revealed by the interpolated bathymetric data, however, approximately 200 $\mathrm{m}$ away from the Kienbergwand, the slope angle is even shallower than $5^{\circ}$. It is thus likely that at least part of the movement during this event occurred as a cohesive flow.
Initially then, it seems probable that rocks and debris entering Lake Mondsee from the southern Kienbergwand rockslope moved downslope as a density-modified grain flow. During movement, in particular when reaching the base of the slope, underlying lacustrine silt and clays as well as fine material resulting from friction among the rockfall debris were added to the moving mass. This resulted in lowering dispersive pressure within the flow and the clasts settled as the flow slowed down, leading to the mud cap on top of the gravel layer. Fine organic material and silts and clays suspended in the water column slowly settled after the deposition of the transported mass, leading to the organic-rich detrital layer topping the MTD.

The deposits of the young event (LT K2), in contrast, show much higher (at least 60\%) amounts of silt to clay, in which the dolomite clasts are embedded. This facies is typical for cohesive flow (mudflow) deposits (Lowe, 1982). Buoyancy and cohesiveness of the matrix, consisting of clay/silt and water, support the bigger fragments during movement. Similar deposits were described in Lake Lucerne, to have resulted from rockfall into the lake and remobilizing lacustrine slope sediments when moving downslope into the basin therewith deforming in situ basin sediments upon the impacting stress by the mass movement (Schnellmann et al., 2006). The latter process also satisfactorily explains the shear deformation in LT K3 observed on the side of the Kienbergwand MTD.

While both emplacement processes reveal different flow behaviour of the mass movement in the deeper waters of the Lake Mondsee basin, the initiation in both cases is most likely a rockfall event into the lake and downward movement along the steep subaquatic lateral slope. The second event and resulting mass flow, however, remobilized and incorporated much more fine-grained material than the first event. A possible explanation for this could be that the second event remobilized part to the proximal deposits from the previous event. Alternatively, the second event might have been of larger magnitude in its initial phase to have affected more lacustrine slope sediments. Due to limited seismic penetration and steep upper slopes near the shoreline reflection, seismic data do not allow us to resolve these processes in further detail.

\subsubsection{Magnitude of the Kienbergwand rockfall}

Similarly, the limited data coverage and resolution do not allow complete mapping of individual rockfalls or constraining either their volumes or those of subsequent subaqueous mass flow deposits. The mappable area of the MTD in the reflection seismic data is limited to within about $200 \mathrm{~m}$ from the shoreline. The volumetric analysis (volume of $47,500 \mathrm{~m}^{3}$, area of $45,300 \mathrm{~m}^{2}$; Fig. 12) of the MTD in this distal part comprises both the AD 1484 and the $A D \sim 1639$ event. If we only take into account the coarse fraction (i.e. the dolomitic gravels belonging to the rockfall mass and neglect the fine fraction which 


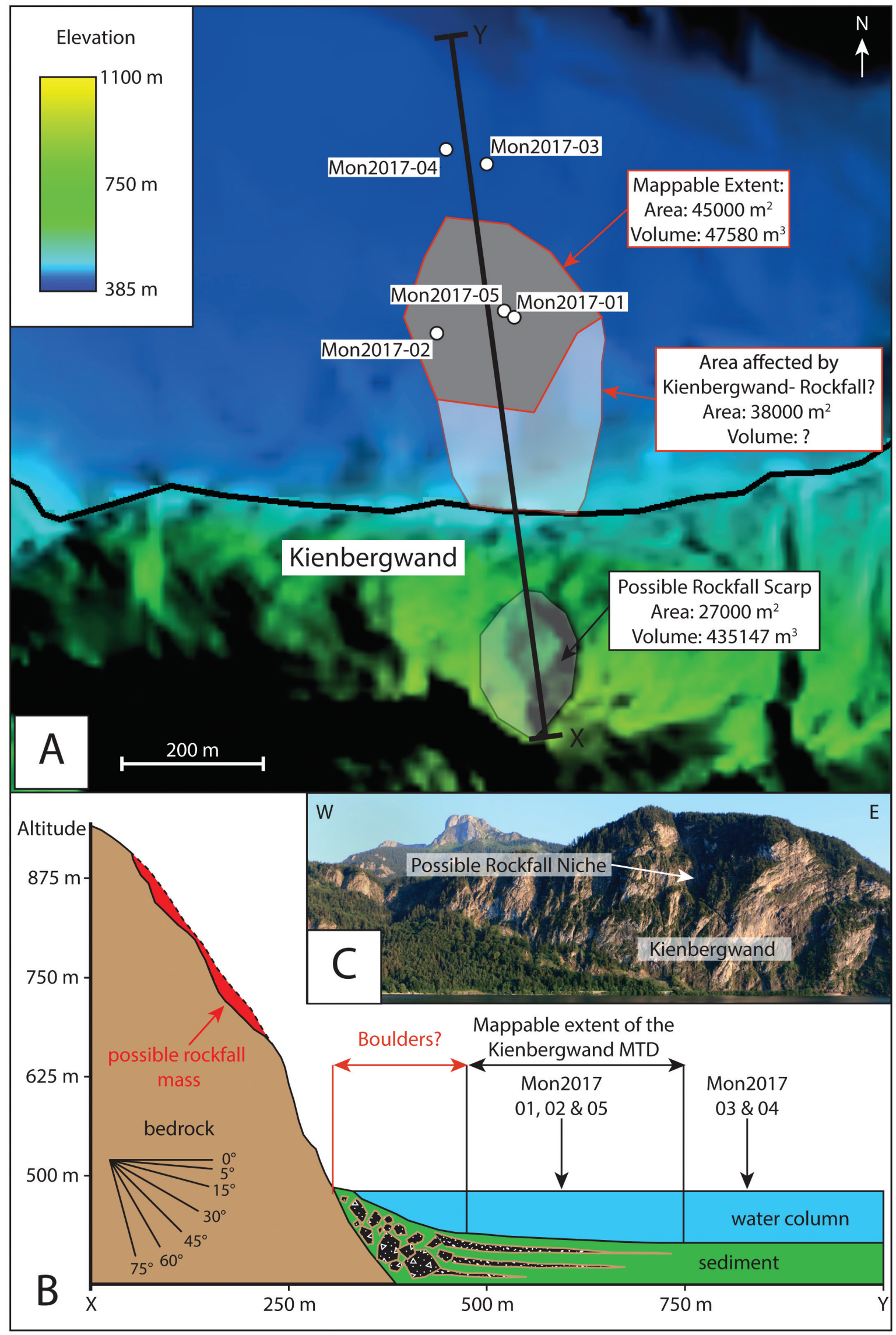

Figure 12: Considerations on the rockfall source and extent at the Kienbergwand on the southern part of Lake Mondsee (Salzkammergut, Austria). A: Elevation model based on digital elevation model ( $10 \mathrm{~m}$; Geoland.at) and bathymetry interpolated from seismic survey. Elevation denoted in meter above sea level. B: Cross section through the Kienbergwand scarp into the Lake basin. See Fig. 12A for course of section. Boulders and coarse rockfall debris is likely to be present in the nearshore area. C: Photograph showing the possible rockfall niche (Riesner, Ohttp://www.mondsee-kultur.at). 
might represent lake-internal lacustrine sediment remobilization) and the observed thicknesses of the MTD as revealed from coring, we find that the mappable volume of rockfall debris is significantly smaller. For the AD 1639 event (LT K2; 70 wt\% dolomitic material, $\sim 50$ vol\%, thickness $7 \mathrm{~cm}$ ), it is $1585.5 \mathrm{~m}^{3}$, for the AD $\sim 1484$ event (LT K1; 20 wt\% dolomitic material, 15 vol\%, thickness $35 \mathrm{~cm}$ ) it is $2378.25 \mathrm{~m}^{3}$. Therefore, these two rockfall phases only resulted in about $4000 \mathrm{~m}^{3}$ of rockfall debris in the mappable area. However, these numbers are at best minimum volume estimates of the entire rock volume that fell into the lake, because a considerable depositional area in the nearshore area is not part of the volume calculations. Schnellmann et al. (2006), for instance, showed that for the AD 1964, rockfall event $\left(\sim 70,000 \mathrm{~m}^{3}\right)$ into Lake Lucerne, Switzerland, the rockfall cone reaches about $300 \mathrm{~m}$ into the lake and the thickness of the respective deposits increases drastically towards the shoreline. Compared to this event, the Kienbergwand rockfall events appear to have been on a considerably smaller scale. The rockfall cone is not visible within $150 \mathrm{~m}$ to the shoreline.

An upper-scale maximal rock volume that might have been mobilized can be analysed by terrestrial digital elevation models of the Kienbergwand rockface. In the hillshade map (Schummerung Land Salzburg, resolution: $5 \mathrm{~m}$ ), an impressive rockfall scarp can be seen (Fig. 12). As it is positioned just south of the Kienbergwand MTD, this might be considered as the potential source area of the Kienbergwand rockfall and its related MTD. Calculations on the data provided by the Digitales Geländemodell Österreich (Digital elevation model of Austria, horizontal resolution: $10 \mathrm{~m}$ ) revealed the volume of the rockfall niche to be between 435,000 and $600,000 \mathrm{~m}^{3}$ (for these calculations, the rockfall volume was assumed to just fill the present niche to the height of its surroundings, which is likely an overestimation of the pre-event rockface topography). Even assuming that two events released this rock volume, the numbers are about one order of magnitude higher than what has been acoustically resolved in the reflection seismic data set and about two orders of magnitude higher than the rock volume estimated from clastic analyses in the sediment cores. However, through comparison to the rockfall event into Lake Lucerne in 1964 (Schnellmann et al., 2006), we interpret the rockfalls from the Kienbergwand as significantly smaller than $\sim 70,000 \mathrm{~m}^{3}$. Thus, the Kienbergwand niche is more likely to be the product of repeated smaller-scale rockfall events than of one or two single large events. This interpretation is supported by our observation in the deeper part of the reflection seismic data set, revealing previous occurrences of similar events in the postglacial evolution of the Lake Mondsee and its surroundings.

In addition, the 1964 event described by Schnellmann et al (2006) in Lake Lucerne is reported to have caused waves up to $15 \mathrm{~m}$ high near the rockfall area and causing substantial damage in the nearshore area $3.5 \mathrm{~km}$ from the impact site (Schnellmann et al., 2006). We cannot exclude that the substantially smaller estimated rockfall events from the Kienbergwand may also have generated impact waves; however, due to the fast dispersion of wave energy with distance it is unlikely that these waves would have severely impacted the shorelines of Lake Mondsee. To the best of our knowledge, there is no historical document that would describe such a phenomenon for the times around AD 1639 and AD 1484. In addition, larger wavegenerating mass movement events intolakes are expected to also remobilize larger amounts of fine-grained material, the deposits of which would form distinct "megaturbidite" deposits, discernible in core and reflection seismic data (e.g. Kremer et al., 2012; Schnellmann et al., 2006). The seismic data of Lake Mondsee, however, show no major irregularity of continuous deposition in the deep basin. This result is especially important as it rules out the Kienbergwand and its immediate surroundings as the source area for any hypothetical "Mondsee Tsunami" (e.g. Breitwieser, 2010; Schulz, 2008).

\subsection{Age and cause of the Kienbergwand rockfall events}

Correlations between the fingerprints left in the distal cores and the varve-dated core Mo-05 (Swierczynski, 2012) yield ages of about AD 1639 for the younger and AD 1484 for the older event. The most prominent evidence for comparable past events as revealed by reflection seismic data dates to about 11,000-12,000 years ago. These data, however, are constrained only by seismic stratigraphic correlation with the age model of Mo-05. Nevertheless, the sparse occurrence of seismically ascertainable MTDs linked to rockfall deposits into Lake Mondsee suggests very low recurrence and thus low probability of an occurrence of such an event.

The trigger mechanisms of rockfalls are manifold. They include strong precipitation, earthquakes and freezethaw processes (Wieczorek and Jäger, 1996; Dorren, 2003). Seismic shaking as a trigger of the Kienbergwand rockfall events is unlikely because there is no other independent evidence of seismic shaking (delta or shore collapses, turbidite deposits, soft-sediment deformation structures: Strasser et al., 2013) present in the sedimentary infill of Lake Mondsee, and at least the two younger events occurred during historic times when one would expect to have some historical documentation for significant earthquake events (Hammerl, 2017).

The age of both MTD events lies within the Little Ice Age (LIA) period, which lasted from about AD 1350 to 1850 in the Alpine region (Wanner et al., 2008). According to the SPA 12 stalagmite record (Mangini et al., 2005), the older event occurred in a warm phase of the LIA, whereas the younger event falls into a rather cold interval. Trachsel et al. (2012), however, reported that during the time period from AD 1630 to 1650, summer temperatures in the Alps were not significantly below the mean summer temperature during AD 1901-2000. In the Swiss Alps, landslide activity increased from 750 to 300 cal. BP (Dapples et al. 2003), whereas Prager et al. (2008), who collected data 
of large mass movements in the Eastern Alps (focusing on Tyrol), found no evidence of big rockfalls during the LIA. Gruner (2006) even showed that between AD 1600 and 1850, the amount of big rockfall and rock avalanche events was rather small compared to warmer periods. Swierczynski et al. (2013) identified 18 intervals of increased flooding during the past 7100 years in Lake Mondsee. Of these intervals, one occurred during the LIA and may therefore be connected to this glacial advance. As our data do not show enhanced rockfall activity during the other flood periods, however, increased precipitation is unlikely to have triggered the Kienbergwand rockfalls. Based on these considerations, we suggest freeze-thaw cycles as the most plausible cause of rockfall activity associated with the Kienbergwand.

\section{Conclusions}

Our combined approach, using both reflection seismic surveys and multiple cores to investigate the sedimentary environments of Lake Mondsee, allows us to formulate the following conclusions:

- The sedimentary infill of Lake Mondsee, which exhibits extensive acoustic blanking due to high sediment and organic matter flux (and its postdepositional degradation) by river inflows in different parts of the lake, consists of at least $60 \mathrm{~m}$ of sediment, with the Holocene only comprising the uppermost $11.5 \mathrm{~m}$. The general seismostratigraphy closely resembles those of other perialpine lakes in France and Switzerland. A distinct seismic unit with high reflection amplitudes, however, may correspond to the glacial advance during the Gschnitz stadial.

- The south-eastern shoreline has been affected by infrequent rockfalls, of which the two biggest events occurred during the Little Ice Age. The Kienbergwand that was responsible for any putative "Mondsee Tsunami" can be excluded, and no evidence of an event of such a scale is present in the seismic record of Lake Mondsee.

- Similar external (rockfall) processes can lead to diverse sedimentological imprints in the nearshore area, based on the sediment predisposition prior to the event.

- On the other hand, different environmental processes (floods, landslides, rockfalls, lacustrine sediment remobilization) can result in similar signatures of detrital layers in the deep lake basin. To accurately interpret the event-layer origins in long basin records, it is necessary to fully understand the spatio-temporal sedimentation patterns of the lakes studied. This can be achieved through reflection seismic surveys and suitably spatially distributed cores.

\section{Acknowledgements}

This study was supported by the FWF-DACH Project (beyond lake villages, FWF Project No. I-1693). We thank the Lake Mondsee sediment coring team: Sandra
Brügger, Willi Tanner, Armin Komposch (University of Bern), Benjamin Dietre and Christophe Adam (University of Innsbruck) as well as Gerald Egger (Verein Pfahlbau am Attersee) for retrieving the cores in 2016. Harald Ployer from the Research Department for Limnology, Mondsee (University of Innsbruck), for piloting the R/V Kühnelt vessel during the seismic surveys and the Geological Institute at ETH Zurich for providing the subbottom profiling equipment are further acknowledged. We also thank Stefan Lauterbach (Leibniz Laboratory for Radiometric Dating and Stable Isotope Research, University of Kiel) for providing high-resolution core photographs for core-to-core correlation and fruitful discussion. IHS Markit for its educational grant program providing the KINGDOM seismic interpretation software, as well as two anonymous reviewers for their thorough reviews, are acknowledged.

\section{References}

Andersen, N., Lauterbach, S., Erlenkeuser, H., Danielopol, D. L., Namiotko, T., Hüls, M., Belmecheri, S., Dulski, P. Nantke, C., Meyer, H., Chapligin, B., von Grafenstein, U. and Brauer, A., 2017. Evidence for higher-than-average air temperatures after the $8.2 \mathrm{ka}$ event provided by a Central European $\delta 180$ record. Quaternary Science Reviews, 172, 96-108. https://doi.org/10.1016/j. quascirev.2017.08.001

Baster, I., Girardclos, S., Pugin, A. and Wildi, W., 2003. High-resolution seismic stratigraphy of an Holocene lacustrine delta in western Lake Geneva (Switzerland). Eclogae Geologicae Helveticae, 96 (Supplement 1), 11-20. https://doi.org/0012-9402/03/01S011-10.

Behbehani, A.-R., 1987. Sedimentations- und Klimageschichte des Spät- und Postglazials im Bereich der Nördlichen Kalkalpen (Salzkammergutseen, Österreich). Göttinger Arbeiten zur Geologie und Paläontologie, 34, 1-120.

Behbehani, A. R., Handl, M., Horsthemke, E., Schmidt, R., and Schneider, J., 1985. Possible lake level fluctuations within the Mondsee and Attersee. In D. L. Danielopol, R. Schmidt, \& E. Schultze (Eds.), Contributions to the paleolimnology of the Trumer Lakes (Salzburg) and the lakes Mondsee, Attersee and Traunsee (Upper Austria) (pp. 136-148). Limnologisches Institut der Österreichischen Akademie der Wissenschaften, Mondsee.

Blum, P., 1997. Physical properties handbook, ODP Tech Note 26. doi:10.2973/odp.tn.26.1997

Breitwieser, R., 2010. Der "Mondsee-Tsunami“ - Fakt oder Mediengag? NAU - Nachrichtenblatt Arbeitskreis Unterwasserarchäologie, 16, 85-91.

Burgschwaiger, E. and Schmid, C., 2001. Seismostratigraphische Untersuchungen der Talfüllung des oberen Trauntales bei Ebensee. In: C. Hammerl, W. Lenhardt, R. Steinacker, \& P. Steinhauser (eds.), 150 Jahre Meteorologie und Geophysik in Österreich. Wien: Zentralanstalt für Meteorologie und Geodynamik, pp. 792-797. 
Bussmann, F., and Anselmetti, F. S., 2010. Rossberg landslide history and flood chronology as recorded in Lake Lauerz sediments (Central Switzerland). Swiss Journal of Geosciences, 103/1, 43-59. https://doi.org/10.1007/ s00015-010-0001-9

Charlet, F., De Batist, M., Chapron, E., Bertrand, S., Pino, M. and Urrutia, R., 2008. Seismic stratigraphy of Lago Puyehue (Chilean Lake District): New views on its deglacial and Holocene evolution. Journal of Paleolimnology, 39/2, 163-177. https://doi.org/10.1007/ s10933-007-9112-3

Cohen, A. S., 2003. Paleolimnology: The History and Evolution of Lake Systems. Oxford, UK: Oxford University Press.

Cukur, D., Krastel, S., Tomonaga, Y., Çağatay, M. N. and Meydan, A. F., 2013. Seismic evidence of shallow gas from Lake Van, Eastern Turkey. Marine and Petroleum Geology, 48, 341-353. https://doi.org/10.1016/j. marpetgeo.2013.08.017

Dapples, A., Oswald, F., Raetzo, D., Dapples, F., Oswald, D., Raetzo, H. and Zwahlen, P., 2003. New records of Holocene landslide activity in the Western and Eastern Swiss Alps: implication of climate and vegetation changes. Eclogae Geologicae Helvetiae, 96/1, 1-9. https://doi. org/10.1007/S00015-003-1078-1

Dorren, L. K. A., 2003. A review of rockfall mechanics and modelling approaches. Progress in Physical Geography, 27/1, 69-87. https://doi.org/10.1191/ 0309133303pp359ra

Egger, H. and van Husen, D., 2009. Geologische Karte der Republik Österreich - Erläuterungen zu Blatt 64 Strasswalchen. Wien.

Finckh, P., Kelts, K., and Lambert, A., 1984. Seismic stratigraphy and bedrock forms in perialpine lakes. Geological Society of America Bulletin, 95/9, 1118-1128. https:// doi.org/https://doi.org/10.1130/0016-7606(1984)95<1 118:SSABFI>2.0.CO;2

Fiore, J., Girardclos, S., Pugin, A., Gorin, G. and Wildi, W., 2011. Würmian deglaciation of western Lake Geneva (Switzerland) based on seismic stratigraphy. Quaternary Science Reviews, 30/3-4, 377-393. https://doi. org/10.1016/J.QUASCIREV.2010.11.018

Geoland.at, (n.d.) Digitales Geländemodell (DGM) Österreich. Retrieved from https://www.data.gv.at/katalog/ dataset/d88a1246-9684-480b-a480-ff63286b35b7

Geologische Bundesanstalt, 2017. Massenbewegungen. Retrieved October 5, 2017, from https://gisgba.geologie.ac.at/gbaviewer/?url=https:/gisgba.geologie.ac.at/ ArcGIS/rest/services/AT_GBA_MASSENBEWEGUNGEN/ MapServer

Gumpinger, C., 2011. Potentialstudie Salzkammergut. Ökologischer Zustand und Verbesserungsmöglichkeiten an den Zuflüssen von Mondsee und Irrsee. Linz. Amt der Oö. Landesregierung, Linz, 176 pp.

Gruner, U., 2006. Bergstürze und Klima in den Alpen: gibt es Zusammenhänge? Bulletin für Angewandte Geologie, 11/2, 25-34. https://doi.org/http://doi.org/10.5169/ seals-226166
Hammerl, C., 2017. Historical earthquake research in Austria. Geoscience Letters, 4/1, 7. https://doi. org/10.1186/s40562-017-0073-8

Heirman, K., De Batist, M., Charlet, F., Moernaut, J., Chapron, E., Brümmer, R., Pino, M. and Urrutia, R. (2011). Detailed seismic stratigraphy of Lago Puyehue: Implications for the mode and timing of glacier retreat in the Chilean Lake District. Journal of Quaternary Science, 26/7, 665-674. https://doi. org/10.1002/jqs.1491

Herrmann, M., 1990. Oberflächenkartierung der Mooswinkelbucht/Mondsee und Untersuchungen zur Tiefenstruktur (Österr. Kt. 1 : 25000, BI. 65/3 Mondsee, Salzkammergut, Österreich). Diplomarbeit, Georg-August-Universität Göttingen, Göttingen, Germany.

Hilbe, M. and Anselmetti, F. S., 2015. Mass Movement-Induced Tsunami Hazard on Perialpine Lake Lucerne (Switzerland): Scenarios and Numerical Experiments. Pure and Applied Geophysics, 172/2, 545-568. https:// doi.org/10.1007/s00024-014-0907-7

Hinderer, M., 2001. Late Quaternary denudation of the Alps, valley and lake fillings and modern river loads. Geodinamica Acta, 14/4, 231-263. https://doi.org/10.1 080/09853111.2001.11432446

Hittenberger, V. R., Mittendorfer, F., Maierhofer, G., Keil, J., Bauer, J., Eder, M. and Czizsek, R., 2006. Tunnel Kienbergwand. Felsbau, 24/1, 18-30.

Huber, A., 1982. Felsbewegungen und Uferabbrüche an Schweizer Seen, ihre Ursachen und Auswirkungen. Eclogae Geol. Helv., 75/3, 563-578. https://doi.org/10.5169/ seals-165242

Irlweck, K. and Danielopol, D. L., 1985. Caesium-137 and lead-210 dating of recent sediments from Mondsee (Austria). Hydrobiologia, 128/2, 175-185. https://doi. org/10.1007/BF00008737

Ivy-Ochs, S., Kerschner, H., Reuther, A., Preusser, F., Heine, K., Maisch, M., Kubik, P. W. and Schlüchter, C., 2008. Chronology of the last glacial cycle in the European Alps. Journal of Quaternary Science, 23/6-7, 559-573. https://doi.org/10.1002/jqs.1202

Jagsch, A. and Megay, K., 1982. Mondsee. In: Seenreinhaltung in Österreich. Wien: Bundesministerium für Land und Forstwirtschaft, 6, 155-163.

Janik, C. V., 1969. Die Pfahlbausiedlung See/Mondsee im Blickfeld landschaftlicher Forschung. Jahrbuch des oberösterreichischen Musealvereines, 114, 181-200.

Kämpf, L., Brauer, A., Swierczynski, T., Czymzik, M., Mueller, P., and Dulski, P., 2014. Processes of flood-triggered detrital layer deposition in the varved Lake Mondsee sediment record revealed by a dual calibration approach. Journal of Quaternary Science, 29/5, 475486. https://doi.org/10.1002/jqs.2721

Kämpf, L., Mueller, P., Höllerer, H., Plessen, B., Naumann, R., Thoss, H., Güntner, A., Merz, B., and Brauer, A., 2015. Hydrological and sedimentological processes of flood layer formation in Lake Mondsee. The Depositional Record, 1/1, 18-37. https://doi.org/10.1002/ dep2.2 
Klee, R. and Schmidt, R., 1987. Eutrophication of Mondsee (Upper Austria) as indicated by the Diatom Stratigraphy of a Sediment Core. Diatom Research, 2/1, 55-76. https://doi.org/10.1080/0269249X.1987.9704985

Kremer, K., Simpson, G. and Girardclos, S., 2012. Giant Lake Geneva tsunami in AD 563. Nature Geoscience, 5/11, 756-757. https://doi.org/10.1038/ngeo1618

Kremer, K., Wirth, S. B., Reusch, A., Fäh, D., Bellwald, B., Anselmetti, F. S., Girardclos, S. and Strasser, M., 2017. Lake-sediment based paleoseismology: Limitations and perspectives from the Swiss Alps. Quaternary Science Reviews, 168, 1-18. https://doi.org/10.1016/j. quascirev.2017.04.026

Lastras, G., Amblas, D., Calafat, A. M., Canals, M., Frigola, J., Hermanns, R. L., Lafuerza, S., Longva, O., Micallef, A., Sepúlveda, S. A., Vargas, G., de Batist, M., van Daele, M., Azpiroz, M., Bascunan, I., Duhart, P., Iglesias, O., Kempf, P., and Rayo, X., 2013. Landslides Cause Tsunami Waves: Insights from Aysén Fjord, Chile. Eos, Transactions American Geophysical Union, 94/34, 297-298. https:// doi.org/10.1002/2013EO340002

Lauterbach, S., Brauer, A., Andersen, N., Danielopol, D. L., Dulski, P., Hüls, M., Milecka, K., Namiotko, T., Obremska, M., and Von Grafenstein, U., 2011. Environmental responses to Lateglacial climatic fluctuations recorded in the sediments of pre-Alpine Lake Mondsee (northeastern Alps). Journal of Quaternary Science, 26/3, 253267. https://doi.org/10.1002/jqs.1448

Löffler, H., 1983. Aspects of the history and evolution of Alpine lakes in Austria. Hydrobiologia, 100/1, 143-152. https://doi.org/10.1007/BF00027427

Longva, O., Janbu, N., Blikra, L. H. and Bøe, R., 2003. The 1996 Finneidfjord Slide; Seafloor Failure and Slide Dynamics. In: J. Locat, J. Mienert and L. Boisvert (eds.), Submarine Mass Movements and their Consequences. Springer, Dordrecht, pp. 531-538). https://doi. org/10.1007/978-94-010-0093-2_58

Lowe, D. R., 1976. Grain Flow and Grain Flow Deposits. Journal of Sedimentary Research, 46, 188-199. https://doi.org/10.1306/212F6EF1-2B24-11D78648000102C1865D

Lowe, D. R., 1982. Sediment Gravity Flows: II Depositional Models with Special Reference to the Deposits of High-Density Turbidity Currents. Journal of Sedimentary Research, 52 (1), 279-297. https://doi. org/10.1306/212F7F31-2B24-11D7-8648000102C1865D

Moernaut, J., De Batist, M., Heirman, K., Van Daele, M., Pino, M., Brümmer, R., \& Urrutia, R. (2009). Fluidization of buried mass-wasting deposits in lake sediments and its relevance for paleoseismology: Results from a reflection seismic study of lakes Villarrica and Calafquén (South-Central Chile). Sedimentary Geology, 213/3-4, 121-135. https://doi.org/10.1016/j.sedgeo.2008.12.002 Moernaut, J., Van Daele, M., Strasser, M., Clare, M. A., Heirman, K., Viel, M., Cardenas, J., Kilian, R., de Guevara, B. L., Pino, M., Urrutia, R. and De Batist, M., 2017. Lacustrine turbidites produced by surficial slope sediment remobilization: A mechanism for continuous and sensitive turbidite paleoseismic records. Marine Geology, 384, 159-176. https://doi.org/10.1016/j.margeo.2015.10.009 Mulder, T. and Cochonat, P., 1996. Classification of Offshore Mass Movements. SEPM Journal of Sedimentary Research, Vol. 66/1, 43-57. https://doi.org/10.1306/ D42682AC-2B26-11D7-8648000102C1865D

Munsell Color (Firm), 2009. Munsell soil color charts.

Namiotko, T., Danielopol, D. L., von Grafenstein, U., Lauterbach, S., Brauer, A., Andersen, N., Hüls, M., Milecka, K., Baltanás, A., Geiger, W., Belmecheri, S., Desmet, M., Erlenkeuser, H. and Nomade, J., 2015. Palaeoecology of late glacial and holocene profundal Ostracoda of pre-Alpine lake Mondsee (Austria) - A base for further (palaeo-) biological research. Palaeogeography, Palaeoclimatology, Palaeoecology, 419/1, 23-36. https://doi. org/10.1016/j.palaeo.2014.09.009

Ndiaye, M., Clerc, N., Gorin, G., Girardclos, S. and Fiore, J., 2014. Lake Neuchâtel (Switzerland) seismic stratigraphic record points to the simultaneous Würmian deglaciation of the Rhône Glacier and Jura Ice Cap. Quaternary Science Reviews, 85, 1-19. https://doi.org/10.1016/j. quascirev.2013.11.017

OTS, 1999. Netze verhinderten größeres Unglück auf Kienbergwand-Landesstraße. Retrieved December 15, 2017, from https://www.ots.at/presseaussendung/OTS_19990830_OTS0126/netze-verhindertengroesseres-unglueck-auf-kienbergwand-landesstrasse

Prager, C., Zangerl, C., Patzelt, G. and Brandner, R., 2008. Age distribution of fossil landslides in the Tyrol (Austria) and its surrounding areas. Natural Hazards and Earth System Science, 8/2, 377-407. https://doi.org/10.5194/ nhess-8-377-2008

Preusser, F., Reitner, J. M. and Schlüchter, C., 2010. Distribution, geometry, age and origin of overdeepened valleys and basins in the Alps and their foreland. Swiss Journal of Geosciences, 103/3, 407-426. https://doi. org/10.1007/s00015-010-0044-y

Rasmussen, S. O., Andersen, K. K., Svensson, A. M., Steffensen, J. P., Vinther, B. M., Clausen, H. B., SiggaardAndersen, M.-L., Johnsen, S. J., Larsen, L. B., Dahl-Jensen, D., Bigler, M., Röthlisberger, R., Fischer, H., Goto-Azuma, K., Hansson, M. E. and Ruth, U., 2006. A new Greenland ice core chronology for the last glacial termination. Journal of Geophysical Research Atmospheres, 111/6, 1-16. https://doi.org/10.1029/2005JD006079

Reimer, P. J., Bard, E., Bayliss, A., Beck, J. W., Blackwell, P. G., Ramsey, C. B., Buck, C. E., Cheng, H., Edwards, R. L., Friedrich, M., Grootes, P. M., Guilderson, T. P., Haflidason, H., Hajdas, I., Hatté, C., Heaton, T. J., Hoffmann, D. L., Hogg, A. G., Hughen, K. A., Kaiser, K. F., Kromer, B., Manning, S. W., Niu, M., Reimer, R. W., Richards, D. A., Scott, E. M., Southon, J. R., Staff, R. A., Turney, C. S. M. and van der Plicht, J., 2013. IntCal13 and Marine13 Radiocarbon Age Calibration Curves 0-50,000 Years cal BP. Radiocarbon, 55/4, 1869-1887. https://doi. org/10.2458/azu_js_rc.55.16947

Reitner, J. M., 2011. Das Inngletschersystem während des Würm-Glazials. In: Arbeitstagung der Geologischen 
Bundesanstalt 2011 - Achenkirch (pp. 79-88). https:// doi.org/10.13140/RG.2.1.3754.1520

Riesner, H., 2014. Klostergeschichte - Gründungssage. Retrieved October 9, 2017, from http://www.mondsee-kultur.at/geschichten.php?nid=41\&us=1

Schadler, J., 1958. Der entleerte Gosausee. Geologische Beobachtungen am Seeboden. In: Jahrbuch des Oberösterreichischen Musealvereins. Linz: Oberösterreichischer Musealverein, 103, 191-218.

Schillereff, D. N., Chiverrell, R. C., Macdonald, N., and Hooke, J. M., 2014. Flood stratigraphies in lake sediments: A review. Earth-Science Reviews, 135, 17-37. https://doi.org/10.1016/j.earscirev.2014.03.011

Schmidt, R., 1991. Diatomeenanalytische Auswertung laminierter Sedimente für die Beurteilung trophischer Langzeittrends am Beispiel des Mondsees (Oberösterreich). Wasser und Abwasser, 35, 109-123.

Schneider, J., Müller, J. and Sturm, M., 1987. Die sedimentologische Entwicklung des Attersees und des Traunsees im Spät- und Postglazial. Mitteilungen der Kommission für Quartärforschung der Österreichischen Akademie der Wissenschaften, 7, 51-78.

Schnellmann, M., Anselmetti, F. S., Giardini, D., McKenzie, J. A., and Ward, S. N., 2002. Prehistoric earthquake history revealed by lacustrine slump deposits. Geology, 30/12, 1131-1134. https://doi.org/10.1130/0091-7613(2 002) $030<1131$ :PEHRBL $>2.0$. CO;2

Schnellmann, M., Anselmetti, F. S., Giardini, D. and McKenzie, J. A., 2006. 15,000 Years of mass-movement history in Lake Lucerne: Implications for seismic and tsunami hazards. Eclogae Geologicae Helvetiae, 99/3, 409-428. https://doi.org/10.1007/s00015-006-1196-7

Schnurrenberger, D., Russell, J. and Kelts, K., 2003. Classification of lacustrine sediments based on sedimentary components. Journal of Paleolimnology, 29/2, 141-154. https://doi.org/10.1023/A:1023270324800

Schultze, E. and Niederreiter, R., 1990. Paläolimnologische Untersuchungen an einem Bohrkern aus dem Profundal des Mondsees (Oberösterreich). Linzer Biologische Beiträge, 22/1, 213-235.

Schulz, M., 2008. Pompeji der Steinzeit. Der Spiegel, 41, 160-162.

Simonneau, A., Chapron, E., Vannière, B., Wirth, S. B., Gilli, A., Di Giovanni, C., Anselmetti, F. S., Desmet, M. and Magny, M., 2013. Mass-movement and flood-induced deposits in Lake Ledro, southern Alps, Italy: implications for Holocene palaeohydrology and natural hazards. Climate of the Past, 9/2, 825-840. https://doi.org/10.5194/ cp-9-825-2013

Sletten, K., Blikra, L. H., Ballantyne, C. K., Nesje, A. and Dahl, S. O., 2003. Holocene debris flows recognized in a lacustrine sedimentary succession: sedimentology, chronostratigraphy and cause of triggering. The Holocene, 13/6, 907-920. https://doi.org/10.1191/0959683603hl673rp

Strasser, M., Monecke, K., Schnellmann, M. and Anselmetti, F. S., 2013. Lake sediments as natural seismographs: A compiled record of Late Quaternary earthquakes in Central Switzerland and its implication for
Alpine deformation. Sedimentology, 60/1, 319-341. https://doi.org/10.1111/sed.12003

Sturm, M. and Matter, A., 1978. Turbidites and Varves in Lake Brienz (Switzerland): Deposition of Clastic Detritus by Density Currents. In: Modern and Ancient Lake Sediments (pp. 147-168). Oxford, UK: Blackwell Publishing Ltd. https://doi.org/10.1002/9781444303698.ch8

Swierczynski, T., 2012. A 7000 yr runoff chronology from varved sediments of Lake Mondsee (Upper Austria). Dissertation, Universität Potsdam, Potsdam, Germany.

Swierczynski, T., Lauterbach, S., Dulski, P., \& Brauer, A., 2009. Die Sedimentablagerungen des Mondsees (Oberösterreich) als ein Archiv extremer Abflussereignisse der letzten 100 Jahre. Klimawandel in Österreich - Die Letzten 20.000 Jahre...und ein Blick voraus, 6, 115-126.

Swierczynski, T., Lauterbach, S., Dulski, P., \& Brauer, A., 2012. Late Neolithic Mondsee Culture in Austria: living on lakes and living with flood risk? Climate of the Past Discussions, 8/6, 5893-5924. https://doi.org/10.5194/ cpd-8-5893-2012

Swierczynski, T., Lauterbach, S., Dulski, P., Delgado, J., Merz, B., \& Brauer, A., 2013. Mid- to late Holocene flood frequency changes in the northeastern Alps as recorded in varved sediments of Lake Mondsee (Upper Austria). Quaternary Science Reviews, 80, 78-90. https://doi. org/10.1016/j.quascirev.2013.08.018

Tourismusverband MondSeeLand, 2017. Tauchen im Mondsee. Retrieved October 9, 2017, from http://mondsee.salzkammergut.at/detail/article/1248-tauchen-immondsee.html

Trachsel, M., Kamenik, C., Grosjean, M., McCarroll, D., Moberg, A., Brázdil, R., Büntgen, U., Dobrovolny, P., Esper, J., Frank, D. C., Friedrich, M., Glaser, R., Larocque-Tobler, I., Nicolussi, K. and Riemann, D., 2012. Multi-archive summer temperature reconstruction for the European Alps, AD 1053-1996. Quaternary Science Reviews, 46, 66-79. https://doi.org/10.1016/j.quascirev.2012.04.021 van Husen, D., 1989. Geologische Karte der Republik Österreich 1:50000 - Kartenblatt 65 Mondsee.

van Husen, D., 2003. Als unsere Seen Gletscher waren die eiszeitliche Entwicklung im Salzkammergut. In J. T. Weidinger, H. Lobitzer, \& I. Spitzbart (Eds.), Beiträge zur Geologie des Salzkammergutes (pp. 215-222). Erkudok Institut Museum Gmunden.

van Husen, D., 2004. Quaternary glaciations in Austria. In J. Ehlers \& P. L. Gibbard (Eds.), Quaternary Glaciations Extent and Chronology (Vol. 2, pp. 1-13). Elsevier. https://doi.org/10.1016/S1571-0866(04)80051-4

van Husen, D. and Egger, H., 2014. Geologische Karte der Republik Österreich - Erläuterungen zu Blatt 65 Mondsee. Wien.

van Rensbergen, P., De Batist, M., Beck, C. and Manalt, F., 1998. High-resolution seismic stratigraphy of late quaternary fill of Lake Annecy (northwestern Alps): evolution from glacial to interglacial sedimentary processes. Sedimentary Geology, 117/1-2, 71-96. https://doi. org/10.1016/S0037-0738(97)00123-1 
Vernet, J.-P., Horn, R. and Badoux, H., 1974. Etude structurale du Léman par sismique réflexion continue. Eclogae Geologicae Helvetiae, 67/3, 515-529.

Wanner, H., Beer, J., Bütikofer, J., Crowley, T. J., Cubasch, U., Flückiger, J., Goosse, H., Grosjean, M., Joos, F., Kaplan, J. O., Küttel, M., Müller, S. A., Prentice, I. C., Solomina, O., Stocker, T. F., Tarasov, P., Wagner, M., and Widmann, M., 2008. Mid- to Late Holocene climate change: an overview. Quaternary Science Reviews, 27/19-20, 1791-1828. https://doi.org/10.1016/j. quascirev.2008.06.013

Wieczorek, G. F. and Jäger, S., 1996. Triggering mechanisms and depositional rates of postglacial slope-movement processes in the Yosemite Valley, California. Geomorphology, 15/1, 17-31. https://doi. org/10.1016/0169-555X(95)00112-I

Wiemer, G., Moernaut, J., Stark, N., Kempf, P., De Batist, M., Pino, M., Urrutia, R., de Guevara, B. L., Strasser, M. and Kopf, A. (2015). The role of sediment composition and behavior under dynamic loading conditions on slope failure initiation: a study of a subaqueous landslide in earthquake-prone South-Central Chile. International Journal of Earth Sciences, 104/5, 1439-1457. https://doi. org/10.1007/s00531-015-1144-8

Wood, D. M., 1985. Some fall-cone tests. Géotechnique, 35/1, 64-68. https://doi.org/10.1680/geot.1985.35.1.64

Received: 13022018

Accepted: 25062018

Christoph DAXER ${ }^{1 *}$, , Jasper MOERNAUT ${ }^{1)}$, Timothy TAYLOR ${ }^{2)}$, Jean Nicolas $\mathrm{HAAS}^{3)}$ \& Michael STRASSER ${ }^{1)}$

1) Institute of Geology, University of Innsbruck, Innrain 52f, 6020 Innsbruck, Austria;

2) Department of Prehistoric and Historical Archaeology, University of Vienna, Franz-Klein-Gasse 1, 1190 Vienna, Austria;

3) Institute of Botany, University of Innsbruck, Sternwartestrasse 15, 6020 Innsbruck, Austria;

*) Corresponding author: Christoph.Daxer@uibk.ac.at 
Online Supplementary Data:

\begin{tabular}{lcccc} 
Core & X-Coordinate (UTM) & Y-Coordinate (UTM) & Water Depth & Reference \\
\hline Mon2016 & 380926 & 5295879 & $63 \mathrm{~m}$ & \\
Mon2017-01 & 381388 & 5295428 & $57 \mathrm{~m}$ & \\
Mon2017-02 & 381276 & 5295404 & $57 \mathrm{~m}$ & \\
Mon2017-03 & 381350 & 5295646 & $63 \mathrm{~m}$ & \\
Mon2017-04 & 381289 & 5295667 & $63 \mathrm{~m}$ & \\
Mon2017-05 & 381373 & 5295435 & $57 \mathrm{~m}$ & \\
Mo-05 & 380308 & 5296081 & $63 \mathrm{~m}$ & Lauterbach et al., 2011; \\
& & & & Swierczynski et al., 2012
\end{tabular}

Supplementary Table 1: Coring Locations at Lake Mondsee (Salzkammergut, Austria).

\begin{tabular}{lccccc} 
Core & Depth $(\mathbf{C m})$ & Lab No. & $\begin{array}{c}\text { Radiocarbon age } \\
\left({ }^{14} \mathbf{C} \text { year BP) } \pm \mathbf{1 ~} \boldsymbol{\sigma}\right.\end{array}$ & $\begin{array}{c}\text { Calibrated radiocarbon } \\
\text { age (AD) 2 } \mathbf{\sigma} \text { ranges }\end{array}$ & Material \\
\hline Mon2017-05 & 60 & $\mathrm{BE}-7132.1 .1$ & $157 \pm 18$ & $1666-1815$ & Bark (Pinaceae indet.) \\
Mon2017-05 & 79.2 & $\mathrm{BE}-7133.1 .1$ & $348 \pm 30$ & $1460-1637$ & Needle (Abies sp.) \\
Mon2017-02 & 106 & $\mathrm{BE}-7134.1 .1$ & $417 \pm 18$ & $1437-1486$ & Twig (Abies sp.)
\end{tabular}

Supplementary Table 2: Radiocarbon Ages performed at the LARA AMS Laboratory (University of Bern, Switzerland) on organic remains from terrestrial plants (for details see Fig. 9). For calibrated ages, only the most probable age is shown. For calibration curves, see supplementary figure 1.

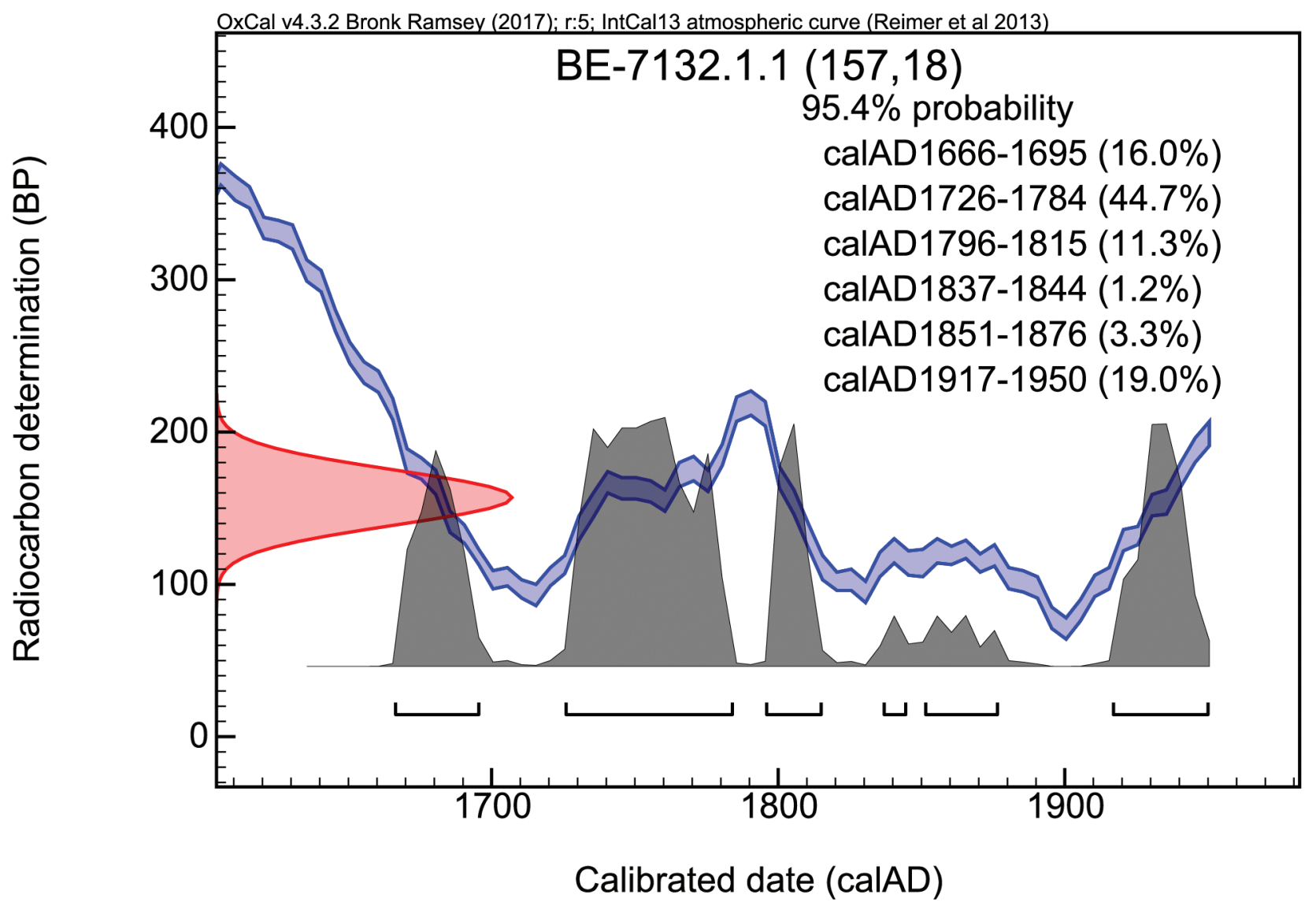

Supplementary Figure 1: Radiocarbon Calibration Curves. 

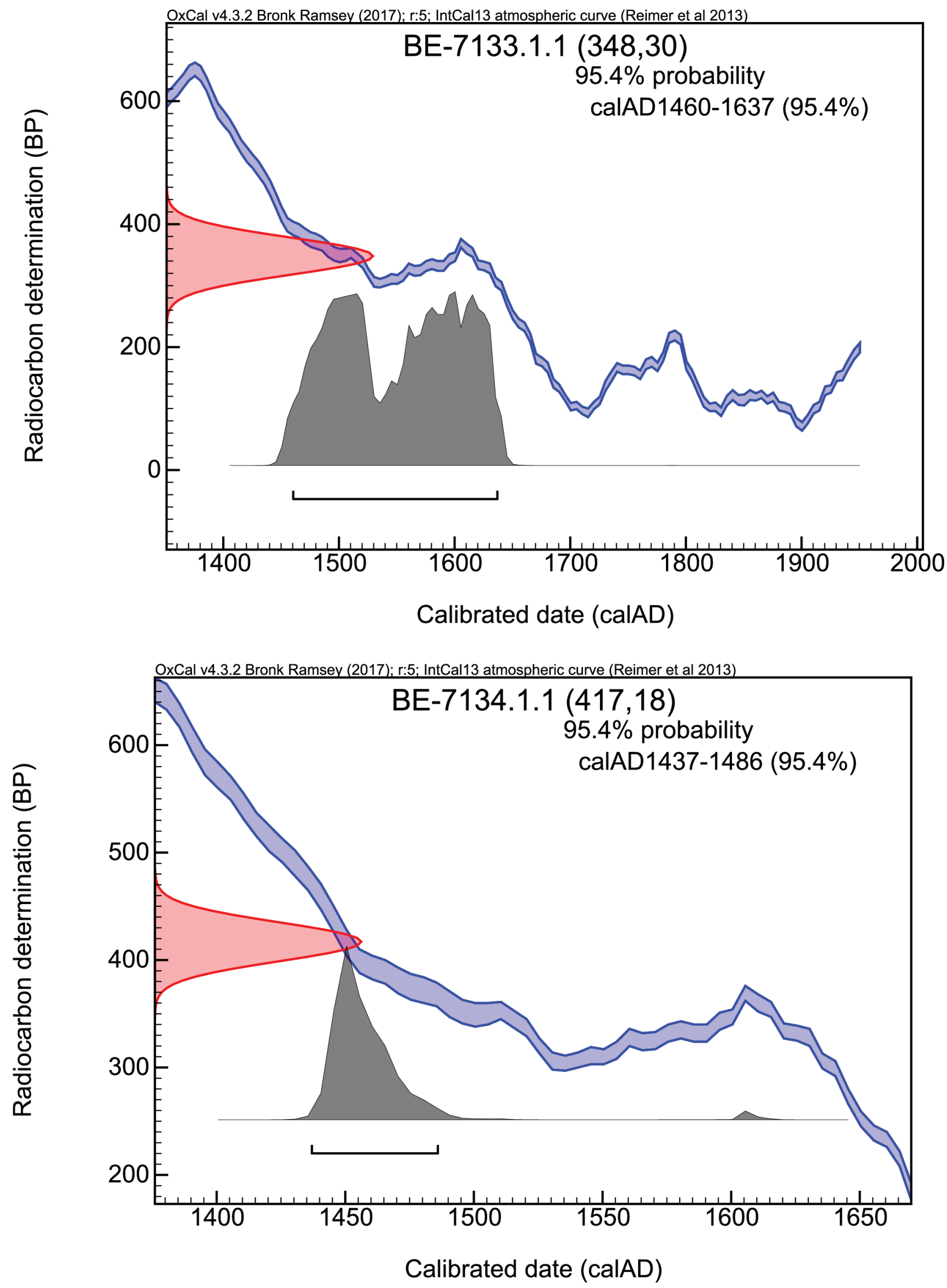

Supplementary Figure 1: Continued. 

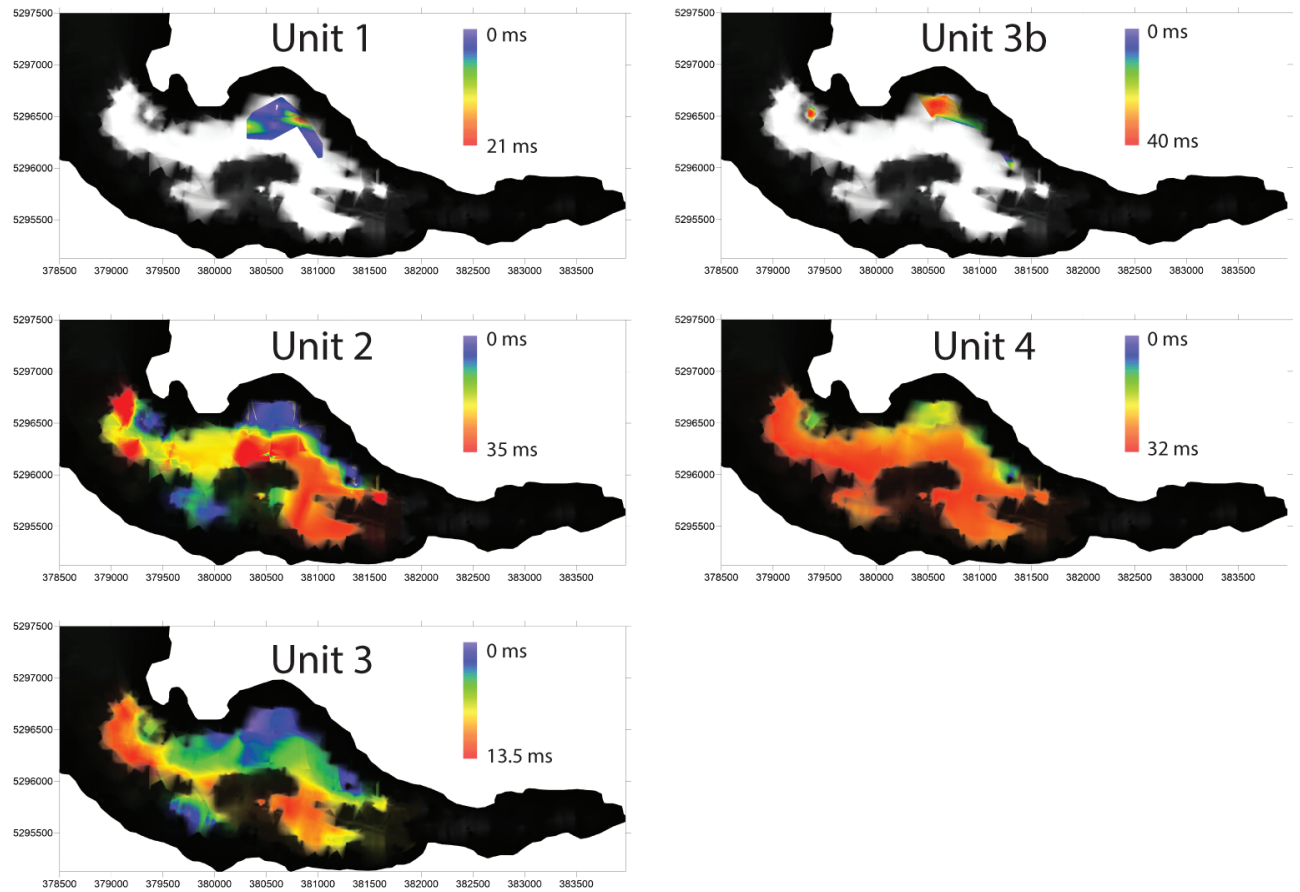

Supplementary Figure 2: Isopach Maps of the Seismic Units. 